\title{
Genealogie manželství*
}

\author{
SHARON MARCUS** \\ Columbia University, USA
}

\section{The Genealogy of Marriage}

\begin{abstract}
The article investigates the practice of female marriages in $19^{\text {th }}$ century Great Britain and United States and argues that female marriages provided model for more progressive forms of the legal marriage between men and women. Unlike homosexuality in the $20^{\text {th }}$ century, the same-sex relationships between women in the $19^{\text {th }}$ century often enjoyed social recognition and some women in female marriages occupied prominent social positions. Because they were considered to rest on contract, female marriages served as inspiration for the contractual view of marriage advocated by many supporters of the Victorian marriage reform. The contribution of women in female couples to the success of the marriage reform was further underlined by their belonging to influential social networks. The author also argues that while the structuralist anthropology of mid- $20^{\text {th }}$ century, represented through the work of Claude Lévi-Strauss, had limited understanding of homosexuality as a socially legitimate phenomenon, the Victorian anthropology of the second half of the $19^{\text {th }}$ century was relatively more open regarding the same-sex relationships. It is contended that authors as diverse as Henry Maine, Johann Bachofen, or Frederick Engels provided impulses in their work both for a positive evaluation of the same-sex relationships and for a more egalitarian understanding of marriage.
\end{abstract}

Keywords: female marriages, social history of marriage, GLBT studies, Victorian studies, social anthropology - history of.

Sociologický časopis/Czech Sociological Review, 2009, Vol. 45, No. 4: 671-706

Má manželství dějiny? A pokud má, jsou to pouze dějiny svazků mezi muži a ženami? Sociální historici odpověděli na první otázku rozhodným ano a během několika posledních desetiletí zmapovali vyvíjející se vztah manželství ke státu, občanské společnosti a soukromému životu, k přátelům a příbuzným, k dobrovolnému souhlasu, smlouvě a rozkoši. Většina z nich ale také pokládala za samozřejmost, že až do velmi nedávné doby se manželství definovalo jako svazek mezi

\footnotetext{
* Adapted and translated into Czech from 'The Genealogy of Marriage.' Pp. 193-226 in Sharon Marcus. Between Women. (C) 2007 by Princeton University Press. Here appearing by permission of Princeton University Press.

** Veškerou korespondenci posílejte na adresu: Prof. Sharon Marcus, English Department, 602 Philosophy Hall, Columbia University, New York, NY 10014, USA; email: sm2247@ columbia.edu.
}

Czech translation (C) Sociologický ústav AV ČR, v.v.i., Praha 2009 
mužem a ženou. ${ }^{1}$ Když v roce 2004 legalizace manželství osob stejného pohlaví ve státě Massachusetts probudila povědomí o tom, že uzavřít manželství touží mnoho stejnopohlavních párů, ukázalo se, že účastníci následné debaty, at’ už stáli na jakékoli straně, považují homosexuální manželství za čerstvý jev s poměrně mělkými historickými kořeny. Odpůrci tvrdili, že manželství osob stejného pohlaví nemá žádnou minulost a zpưsobí konec dějin, a dokonce je označovali za hrozbu pro „nejzákladnější instituci naší civilizace“ . ${ }^{2}$ Příznivci těchto manželství na ně pohlíželi jako na nový fenomén, který se stal možným jen díky velmi nedávnému propojení hnutí za občanská práva homosexuálů s modernizací heterosexuálního manželství. Stephanie Coontz [2005] to ve své obhajobě svazků osob stejného pohlaví vyjádřila následovně: „Gayové a lesby prostě jen sledovali revoluci uskutečňovanou heterosexuály a všimli si, že s novými normami může být manželství zajímavé i pro ně. ${ }^{\text {”3 }}$

Proměny $\mathrm{v}$ heterosexuálním manželství byly tím, co umožnilo lesbické a gay svazky, ale tento vliv nebyl jen jednosměrný. Déle než jedno století přispívaly svazky osob stejného pohlaví k inovacím $\mathrm{v}$ oblasti heterosexuálních manželství. Platí sice, že až do velmi nedávné doby bylo legální manželství dostupné pouze párům složeným $\mathrm{z}$ osob opačného pohlaví, většina lidí pokládala za samozřejmost, že manželství se uzavírá mezi muži a ženami, a lesbické aktivistky i gay aktivisté řadu desetiletí manželství kritizovali a nedožadovali se práva na ně (mnozí v tom stále pokračují). Ale význam manželství se nevyčerpává jeho právní definicí a sociálně přijímané formy manželství existující mimo zákon již hodně dlouho ovlivňují právní změny této instituce. Páry osob stejného pohlaví nemusely čekat, až heterosexuálové dají manželství flexibilnější podobu. Ony samy pomohly dosáhnout této flexibility tím, že manželství užívaly jako model pro své vztahy a aktivně usilovaly o změnu zákonů upravujících svazky mezi muži a ženami.

Svazky osob stejného pohlaví jsou součástí dějin manželství přinejmenším od 19. století. Vztahy mezi ženami ve viktoriánské Anglii zahrnovaly ženy, které společně žily, společně vlastnily majetek, zavazovaly se jedna druhé věrností a samy sebe označovaly za manželky, stejně jako je tak označovaly i další příslušnice jejich sociálních sítí. Ženy žijící v ženských manželstvích vytvářely

\footnotetext{
${ }^{1}$ K sociální historii manželství v Anglii viz Stone [1979] a Gillis [1985]. John Boswell [1994] tvrdil, že ve středověkých křestanských církvích probíhaly obřady spojující muže do vztahů podobných manželství, ale jeho teze novější bádání o moderním manželství neovlivnila.

${ }^{2}$ Řeč prezidenta George W. Bushe z února 2004, v níž se vyslovil pro ústavní dodatek zakazující manželství mezi osobami stejného pohlaví [Bush 2004]. Podobně i ve Francii politici vyjadřují obavu, že svazky osob stejného pohlaví zničí symbolický rád naší kultury. O diskusích ve Francii Eribon [2005]; Lucey [2003: 15] a Butler [2004: 110-23].

3 Také George Chauncey [2004: 34] tvrdí, že zájmu lesb a gayů o manželství předcházely a poskytly zázemí změny v heterosexuální kultuře a heterosexuální „akceptace sexuálních vztahů jako zdroje rozkoše ... dodala lesbám, bisexuálům a gayům odvahu a sebedůvěru.“
} 
vztahy, které podobně jako právní manželství plnily role, jež byly v 19. století přisuzovány sexualitě: správu společné domácnosti, převod vlastnictví, vyjádření emocionálních náklonností a náboženských citů, rozvoj vlastní osoby a péči o sebe. ${ }^{4}$ Prostřednictvím individuálně sepisovaných právních smluv mohly ženy žijící v ženských dvojicích získat některá práva, která stát automaticky uděloval sezdaným párům. Jejich právní status neprovdaných žen jim umožňoval mít sociálně uznávanou partnerku a přitom si udržet ekonomickou autonomii, již právně sezdané manželky ztrácely podle nauky o podřízenosti ženy manželovi. ${ }^{5}$ Ženy žijící v ženských manželstvích tak patřily k avantgardě hnutí za modernizaci manželství, protože jejich vztahy předjímaly rostoucí rovnost mezi manželi a manželkami, jež byla postupně v průběhu 19. a 20. století vtělována do zákona. Na konkrétnější úrovni některé ženy žijící v ženských manželstvích sehrály drobnou, ale klíčovou roli při prosazování občanského rozvodu, práva manželky na vlastnictví a opatrovnictví dětí a rozšíření příležitostí pro neprovdané ženy. Ačkoli ženská manželství byla výjimkou a nikoli pravidlem, ženy, které v nich žily, mohly mít $\mathrm{v}$ dějinách manželství důležitou úlohu, protože byly členkami sociálních sítí zahrnujících zákonodárce, žurnalisty, aktivisty a antropology. Jak ř́ká Michael Lucey [2003: xxvii], byly to aktérky, „které působí v rámci sociálních forem a současně i na ... tyto sociální formy." Tlaky vyvíjené formami příbuzenství existujícími mimo zákon, ale v rámci sociálního světa byly faktorem, který rozhodujícím způsobem přispěl $\mathrm{k}$ tomu, že se z manželství stala tvárná instituce.

Stejně jako „homosexualita“ je nedávným vynálezem, je jím i protiklad mezi manželstvím a homosexualitou. A dějiny svazků osob stejného pohlaví nejsou shodné s utvářením lesbické a gay identity, neboť tyto svazky existovaly dávno předtím, než sexuologie vynalezla „inverta“. Až když v 80. letech 19. století autoři lékařských pojednání a sociální myslitelé začali ztotožňovat inverzi s dětinskostí, primitivismem a rozkladem civilizace založené na monogamním heterosexuálním manželství, začala se homosexualita jevit jako antiteze manželství. Od té doby mnozí autoři propojení mezi homosexualitou a primitivismem ještě dále upevnili výstrahami, že gay manželství povede k nediferencovanému předspolečenskému stavu, v němž je cokoli dovoleno. Jak v roce 2002 prohlásil ve svém známém výroku americký senátor Rick Santorum, pokud by právo na soukromí bylo rozšířeno na homosexuální sex, pak „máte právo na bigamii, právo na polygamii, právo na incest, právo na cizoložství. Máte právo na cokoliv“" [Hertzberg 2003: 33]. V tomto vidění je homosexuální sex natolik vzdálen společenskému řádu, že je s to zvrátit civilizační vývoj a kulturu uvrhnout zpět do přírodního stavu.

I když zastává zcela opačné politické stanovisko, Gayle Rubin použila podobnou argumentaci ve své zásadní eseji „Obchodování se ženami“ z roku 1975.

${ }^{4}$ Michael Lucey rozpracovává tuto definici sexuality ve své syntéze Pierra Bourdieu a Michela Foucaulta [Lucey 2003: 18, 28, 150].

5 Překlad termínu "coverture“, doslova "pokrytí“. Tento právní koncept, platný v anglosaském právu až do druhé poloviny 19. století, přiděloval manželce, označované jako „femme couverte“, podřízený právní status ve vztahu k manželovi (pozn. překl.). 
Jak známo, konstatovala zde, že kritika antropologických a psychoanalytických teorií kultury homosexualitu odsouvá do předkulturní oblasti: „(T)abu incestu předpokládá předchozí, méně zřetelně artikulované tabu homosexuality. Zákaz některých heterosexuálních svazků stojí na tabu neheterosexuálních svazků." $\mathrm{V}$ předznamení teze, kterou rozvinula v práci Gender trouble a dalších svých textech Judith Butler, Rubin [1975: 180] ukázala, že antropologické teorie příbuzenství, jež postulují incestní tabu a směnu žen mezi muži jako nezbytné pro vznik kultury, současně vylučují homosexualitu z civilizace, a vytvářejí tak mezi nimi implicitní rovnocennost. ${ }^{6}$ Když zdůrazňují, že incestní tabu a tabu homosexuality jsou tím, co umožňuje sociální a psychickou koherenci, psychoanalýza a strukturální antropologie vyvolávají přízrak toho, že legitimizace homosexuality rozloží samotnou strukturu příbuzenství.

Homosexualita je skutečně tím, co straší v Elementárních strukturách př́buzenství (1949) Clauda Lévi-Strausse, jednom z hlavních textů, jež Rubin používá, ale je zajímavé, že Lévi-Strauss homosexualitu s incestem nebo předkulturní sférou nespojuje. Lze chápat, o co se opírá teze Rubin, podle níž Lévi-Straussova koncepce incestního tabu předpokládá předchozí tabu homosexuality, protože Lévi-Straussova teorie není nijak zvlášt' nakloněna možnosti formalizovaných vztahů mezi osobami stejného pohlaví a jen málo z ní lze v dnešní době vytěžit pro progresivní sexuální politiku. „(P)ravidla příbuzenství a manželství," píše Lévi-Strauss [1969: 490], „,nejsou vynucena společenským stavem. To ona jsou společenský stav. ${ }^{17}$ Pravidlem manželství je zákaz incestu, jenž upravuje vztah mezi pohlavími jakožto př́íkaz, že muži musí směňovat ženy (23). Z toho by vyplývalo, že sexuální vztahy nezahrnující směnu žen muži nemohou být součástí společenského stavu. Lévi-Strauss v souladu s tím zavrhl teorie příbuzenství závislé na tom, co nazýval „feminismem“ - čímž mínil každé vysvětlení, jež dávalo ženám autonomii a schopnost jednat. V tomto smyslu byla strukturální antropologie 40. let 20. století méně náchylná uznat možnost ženské autonomie než její viktoriánští předkové $s$ jejich výklady raného matriarchátu a polyandrie. Viktoriánští antropologové však také tvrdili, že v primitivních společnostech neexistovala incestní tabu. Výrokem, že incestní tabu je univerzální, propůjčil Lévi-Strauss primitivním společnostem strukturu a socialitu - a současně propojil „společenský stav" s manželstvím definovaným jakožto autorita mužů nad ženami a s kulturou chápanou jako soubor pravidel vyžadujících od mužů směnu žen.

Je však překvapivé, že Lévi-Strauss byl ochoten uznat i sociální povahu homosexuality. Poznamenal, že homosexualita a bratrská polyandrie mohou být

\footnotetext{
${ }_{6}$ V knize Gender trouble Judith Butler [1990, slovensky 2003] argumentaci Gayle Rubin rozšírila do podoby zásadní kritiky „heterosexuální matrice“ a zákaz incestu viní z vytváření genderové identity jakožto heterosexuality. Ve své další práci Antigonin nárok Butler [2000: 66] tento názor modifikovala a tvrdí, že je třeba rozlišovat mezi zákazy incestu a zákazy homosexuality a oddělit př́ibuzenství od heterosexuality.

${ }^{7}$ Všechny další odkazy na tuto knihu se vztahují ke zde citovanému vydání a jsou uvedeny v závorce prímo v textu.
} 
„ک̌rešením“ nedostatku manželek (38). ${ }^{8}$ V odpovědi na tvrzení Brendy Seligman, že pokrevní bratrství „zpochybňuje fakt, že žena je jediným nebo hlavním nástrojem př́buzenského spojováni“", Lévi-Strauss připustil: "Jsme daleci toho tvrdit, že směna nebo darování žen je jediným způsobem vytváření příbuzenských pout v primitivních společnostech" (483). Prohlásil dokonce, že on sám ještě dříve než Seligman ukázal, že v některých skupinách křížový bratranec a potenciální švagr ,je tím, s kým je zvykem se v adolescentním věku pouštět do homosexuálních aktivit“ (484). To znamená, jak dále doplnil, že švagrové jsou tíž, "at' už hrají roli opačného pohlaví v erotických hrách dětského věku nebo jejich maskulinní spojenectví jakožto dospělých je potvrzováno tím, že každý dává druhému to, co nemá - manželku -, když se přitom oba současně vzdávají toho, co mají - sestry" (484).

Lévi-Strauss uznával homosexualitu pouze do té míry, v jaké ji mohl podřídit pod heterosexualitu, ale přitom homosexualitu charakterizoval jako kulturní fenomén, jako formu spojenectví v sociálním světě a z něj nevykázanou. Univerzálnost incestního tabu neznamená, že homosexualita je také tabu, ale že i sama homosexualita je vposledku ř́zena zákazem incestu a imperativem exogamie. Proto může tvrdit, že homosexuální vztahy jsou řízeny stejnými pravidly směny jako vztahy heterosexuální: „(M)anželství slouží jako model pro onu umělou a dočasnou ,družnost' mezi mladými lidmi stejného pohlaví vyskytující se na některých školách, o níž Balzac činí hlubokou poznámku, že se nikdy nepřekrývá s pokrevními pouty, ale nahrazuje je“ (480). Umělá, dočasná, imitativní družnost - Lévi-Strauss stěží připouštěl existenci homosexuality jako takové. Ale právě proto, že ji sotva byl schopen chápat jako odlišnou od heterosexuality, nerozlišoval mezi heterosexualitou a svazky osob stejného pohlaví a homosexualitu nezasadil do primordiálního přírodního stavu před zákazem incestu.

\section{Ženské manželství v 19. století}

Příslušníci ctihodné viktoriánské společnosti také dovedli vnímat ženy jakožto sezdané jedna s druhou a málokdy směšovali ženská manželství mezi bílými ženami ze střední třídy s polygamními nebo incestními svazky, jež přisuzovali národům, které se snažili si podmanit, přičemž imperiální poslání bylo ospravedlňováno křestáanskými ideály manželství. Život Charlotte Cushman (1816-1876), zdokumentovaný v dopisech a pamětech, dokládá, že i žena, která měla nedovolený poměr se svou snachou, rozlišovala mezi tímto nedovoleným, téměř incestním poměrem a více manželství se blížícím vztahem udržovaným plně na očích jejích přátel a veřejnosti se ženou, již označovala za svou manželku. Charlotte Cushman byla jednou z nejoslavovanějších a finančně neúspěšnějších amerických hereček 19. století, známou zejména rolí Romea ze 40. let. Ač se narodila ve Spojených státech, většinu svého života prožila jinde. Nejdříve v Anglii a poté v Itálii,

8 Francouzský výraz je „homosexualité" [Lévi-Strauss 1981: 44]. 
ale do USA se často vracela při svých vyprodaných turné po celé zemi. Lisa Merrill ve své vynikající biografii ukázala, že Cushman používala jazyka manželství k tomu, aby konceptualizovala řadu svých sexuálních vztahů k ženám, které poté, co se z ní stala hvězda, obvykle sestávaly z primárního vztahu se stejně starou partnerkou a sekundárního tajného vztahu s mnohem mladší ženou, zpravidla obdivovatelkou [Merrill 1999: 150]. ${ }^{9}$ Cushman své primární vztahy popisovala jako manželství vytvářející partnerské pouto a příbuzenskou sít. V roce 1844 si poznamenala do deníku: „Spala jsem s Rose“ a následující den pokračovala: „,R.' sobota 6. července ,svatba“" (9). Stejně jako v heterosexuálním manželství i zde sex vytvářel manželství a manželství zakládalo př́ibuzenství: Cushman říkala Roseinu otci "otče“, jako by byl jejím tchánem nebo jako by se sňatkem s Rose stala její sestrou (74).

Cushman měla dlouhodobé vztahy se dvěma ženami: se spisovatelkou, překladatelkou a feministkou Matildou Hays a se sochařkou Emmou Stebbins, s níž se potkaly v roce 1857 . Stebbins je dnes známá především díky své soše Anděl vod, která se nachází na terase Bethesda v Centrálním parku v New Yorku a hraje důležitou roli ve hře Tonyho Kushnera Andělé v Americe. Až do své smrti v roce 1876 si Cushman pěstovala veřejnou tvář jako uznávaná umělkyně a přitom neskrývaně žila s Emmou Stebbins v elegantním bytě neustále přeplněném přáteli a domácími zvířaty. Po smrti Cushman napsala Stebbins její životopis, který se zámlkami a neosobním tónem typickými pro biografické psaní oné doby obsahuje pouze jednu přímou zmínku o jejich vztahu: „V zimě 1856-1857 se autorka těchto memoárů poprvé seznámila se slečnou Cushman a od té chvíle proudy jejich životů s nemnoha výjimkami ubíhaly vedle sebe." Ale Stebbins potvrdila své manželské spojení s Cushman už samotným faktem, že životopis napsala jako své memoáry, zřetelným potlačením zmínek o dalších milenkách své partnerky, podrobným líčením jejich společného bytu v Římě a desetistránkovým inventářem jejich zvířecích miláčků zahrnujících psy Teddyho a Bushie [Stebbins 1879: 100]..$^{10}$

Jedno z jejich mnoha domácích zviŕat se stalo námětem chvalozpěvu, jejž napsala Isa Blagden, spisovatelka, která žila ve Florencii a se Stebbins a Cushman se přátelila. Složila pro ně báseň „Drahé staré Bushie. Od té, co ji milovala“, kterou Stebbins cituje ve svém životopise $\mathrm{v}$ plném znění. Bylo by naivní myslet si, že si viktoriáni neuvědomovali konotace jména „Bushie“ jako důvěrného označení pro ženské genitálie. Uživání zájmen místo vlastních jmen v podtitulku „Od té, co ji milovala“ nás vybízí k tomu, abychom báseň četli symbolicky jako lamento nad

\footnotetext{
9 Všechny další odkazy na tuto knihu se vztahují ke zde citovanému vydání a jsou uvedeny v závorce přímo v textu.

${ }_{10}$ Popis jejich společného domu viz [Stebbins 1879: 114-5]; popis jejich služebnictva, těchto dalších "„členů domácnosti“ [116-21]; o domácích zvířatech [112-31]. Merrill [1999: 251] vykládá vyhýbání se zmínkám o bývalých milenkách Cushman snahou odstranit otevřené odkazy k lesbismu, ale spíše se zdá, že u Stebbins jde o nenápadné přiznání vlastnického vztahu k předmětu její biografie.
} 
milovanou fenkou a jako anticipaci smrti milované ženy. Tato záměna je usnadněna rétorickým rozhodnutím básně oslovovat nepřítomné zvíře přímo v druhé osobě jako nejmenovaného, ale zosobněného partnera v rozmluvě: „Tolik milující a tolik milovaná, troufám si / svou slabou, umdlévající chválou / připomenout tvou ryzí věrnost / tvou trpělivost a lásku / tvůj roztoužený, dychtivý, rychlý dech / jímž dostihuješ naše otupené smysly / slavnostní výraz v očích tvých / jasnější nad vyřčená slova?" Zbývající část básně říká, že zvířata se vyrovnají lidem v lásce a věrnosti, a končí takto: „Láska dlouhá jak život leží v tvém prachu / snese snad lidský hrob víc?" [citováno ve Stebbins 1879: 126-7] Svým dưrazem na opravdovou oddanost vášnivé lásky, jež zůstává nevyslovena, báseň vyjadřuje nefalšovanou náklonnost Blagden k Bushie a její ocenění pro „lásku dlouhou jak život" mezi dvěma ženami, s nimiž fenka žila."

Sama Cushman označila svůj vztah ke Stebbins za manželství, když upozorňovala svou mladou milenku Emmu Crow na to, že není svobodná; řekla jí: „Nevíš, že jsem už vdaná a nosím toho odznak na prostředníku své pravé ruky?" (211). Cushman začala tajný vztah s mnohem mladší Crow v roce 1858, krátce poté, co si s Emmou Stebbbins vyměnily prsteny a začaly spolu žít. Cushman a Crow se potkaly, když byla Cushman na turné po Spojených státech; jejich románek trval léta, odehrával se na různých kontinentech a je doložen $\mathrm{v}$ mnoha dopisech, které Cushman Crow psala. Crow je uchovala a odkázala Knihovně Kongresu navzdory mnoha naléhavým výzvám své milenky, aby je spálila. V dopisech se Cushman často snažila naturalizovat svou cizoložnou zradu na Emmě Stebbins tím, že mladší Emmu Crow nazývala svou dcerou, neteří a dítětem, jako by chtěla naznačit, že Crow nebyla pro Stebbins sokyní, ale jen prŕrůstkem do rodiny. Cushman psala: „Nikdy žádná matka tak nemilovala své dítě. Nikdy žádná tetička nemyslela tak sladce a toužebně na svou neteřinku. Nikdy žádna žena tak silně nemilovala svého milence“" [citováno v Markus 2000: 175].

Cushman dotáhla incestní fantazie o sexu jako př́buzenství do naprosté krajnosti, když vyzvala Crow, aby se provdala za jejího synovce a adoptivního syna Neda Cushmana. Jejím cílem bylo zařídit, aby Crow žila v její blízkosti jako její snacha, proti čemuž manželka Emma Stebbins nemohla nic namítat. Láska Crow ke Cushman byla tak silná, že s návrhem souhlasila a ve vztahu s Cushman pokračovala ještě dlouho poté, co sňatek Crow s Nedem udělal z Charlotte Cushman tchyni mladé Emmy a tetičku dětí, které Emma s Nedem měla. I po svatbě Crow s Nedem Cushmanem Charlotte nadále oslovovala Emmu jako svou milenku, ale také jako "drahou novou dceru“, která se tím, že přijala př́ijmení Cushman, v jistém smyslu stala také její manželkou. Charlotte Cushman mluvila o Emmině manželství s Nedem jako o svém „konečném a naprostém spojení“

${ }^{11}$ Společné domácí zvíře bylo běžným tropem ženských manželství. Katherine Bradley a Edith Cooper, které žily spolu a psaly pod společným jménem Michael Field, tvořily oddanou trojici se svým psíkem jménem Whym Chow, kterého považovaly za prostředníka jejich svazku [viz Roden 2002: 191-99]. O blízkosti mezi homoerotickou láskou a láskou ke zvíratům viz také Vanita [1996: 215-41]. 
s Emmou a ve svých dopisech těhotné Emmě dávala najevo, jak na to upozorňuje autorka jejího životopisu Lisa Merrill, ,že ona a její ,malá milenka' mají toto dítě společně." S grandiózností vlastní bohaté a slavné herečce si Cushman přivlastňovala role manžela, manželky, otce, matky, tety i milenky najednou. Emmu oslovovala „nejdražší a nejsladší dcero(,) neteři, přítelkyně a milenko" a zase v jiných dopisech samu sebe nazývala „velkou mámou“ [Merrill 1999: 221, 223, 217, 226, 231, 230].

Matrilineární, incestní, cizoložná, polygamní a homosexuální domácnost Charlotte Cushman zdánlivě naplňuje konzervativní fantazii primitivní rodiny, v níž se nedělají rozdíly mezi ničím, nevnucují se žádná omezení a patriarchální monogamie nedrží na uzdě promiskuitu vznikající při ničím nespoutané nadvládě žen. Právě z tohoto důvodu Cushman nabízí vynikající východisko, z něhož lze zpochybnit ztotožnění homosexuality s primitivní sexuální anarchií. Její románek s Emmou Crow totiž neukazuje, že ti, kdo ignorují tabu homosexuality, budou ignorovat také zákazy incestu a polygamie. Dokládá naopak, že tak jako v př́padě většiny viktoriánů byly touhy Charlotte Cushman ovlivňovány tabu, jež podněcovala tytéž touhy, které zakazovala. Slib monogamie, ač právně nezávazný, činil cizoložství tím lákavějším, a jak Foucault ukazuje v prvním dílu Dějin sexuality, nic nebylo ve viktoriánských rodinách tak normativní jako jejich posedlost incestem. Ve společnostech, kde je „rodina nejaktivnějším ohniskem sexuality ... zaujímá incest centrální místo ...; je nepřetržitě vyžadován i odmítán, je utkvělou představou i výzvou, skrytou obavou i nezrušitelným poutem. Ukazuje se jako něco, co je v rodině důrazně zakázáno ...; je však také tím, co je neustále žádáno, nebot' rodina je ohniskem trvalého podněcování sexuality“ [Foucault 1999: 127-8]. Osa matka-dcera podléhala erotizaci stejně jako každý jiný aspekt rodinného života a incestní fantazie, skryté nebo otevřené, byly vyčnívajícím rysem viktoriánské kultury. Dopisy Charlotte Cushman Emmě Crow rozmazávaly hranici mezi milenkou a členkou rodiny stejným způsobem, jako to činí Dinah Mulock Craik ve svém románu Olivovník z roku 1850, když líčí lásku manželky k jejímu manželovi: „Milovala ho současně láskou matky, sestry, přítelkyně a manželky“ [Craik 1999: 314]. Pornografické romány obsedantně zobrazovaly incest všech možných druhů a ve všech možných genderových konfiguracích a Henry James mohl snadno přenést jemu známý prríběh Charlotte Cushman do heterosexuální zápletky Zlaté čǐše, v níž se otec ožení s milenkou manžela své dcery, jež se také jmenuje Charlotte. ${ }^{12}$

Normativní povaha i těch nejskrytějších tužeb Charlotte Cushman napomáhá k vysvětlení, proč nebyla během svého života ocejchována jako deviant a proč vztahy se ženami, které udržovala na veřejnosti, byly osobami v jejím okolí

\footnotetext{
${ }^{12}$ Henry James věnoval pozornost Cushman a Hosmer v knize William Wetmore Story a jeho prátelé, kde o jejich italských kariérách napsal, že „nás nejspíš dovedou na stezky křivé (queer) a klikaté“ [James 1969: 258]. Markus si všímá souvislosti mezi skutečností, že se James znal s kroužkem kolem Cushman, a zápletkou Zlaté čiše. Neuniká jí ani to, že Emma Crow Cushman během manželství s Nedem i po Nedově smrti nadále udržovala milostné poměry se ženami [Markus 2000: 72-3, 231, 282].
} 
přijímány. Cushman byla uznávaná a často obdivovaná postava: žena z 19. století, která díky své finanční nezávislosti mohla poměrně snadno vytvořit pár s jinou ženou. Cushman ráda hrála na jevišti mužské role a jako mnoho dalších středostavovských žen a aristokratek v ženských manželstvích nosila mužské oblečení a používala mužské přezdívky. ${ }^{13}$ Avšak žila otevřeně s jinými ženami jako žena a identifikovala se s ženskými i mužskými rolemi. Cushman označovala Emmu Stebbins za svou lepší polovičku a mluvila o tom, že je provdaná za svou první milenku, Rose, ale nepovažovala samu sebe důsledně ani výlučně za manžela. Jazyk manželství vyjadřoval spíše kvalitu jejího závazku vůči sexuální partnerce než genderovanou dělbu rolí. $V$ tomto ohledu se ženské manželství na základě dnešních historických poznatků jeví jako fenomén typický primárně pro střední a vyšší vrstvy. Ženy z dělnické třídy, které samy vydělávaly, také tvořily páry s jinými ženami, ale bylo zde běžnější, že jedna členka páru žila jako muž. Takové svazky proto nebyly pokládány za ženská manželství. I když je lze v určitém technickém smyslu pokládat za manželství mezi ženami, před zákonem, společenstvím lidí kolem páru a párem samotným šlo o manželství mezi ženou a mužem. Pokud byly chyceny a odhaleny jako ženy, některé ženy-manželé byly právně postiženy a zesměšněny $\mathrm{v}$ písních za to, že si přivlastňovaly mužská privilegia, ale jiným se to nestalo. ${ }^{14}$ Článek o "Moderních Amazonkách" [Gleanings 1863: 348-49] kupříkladu souhlasně psal o dvou ženách, které si osvojily role „muže a manželky“" a ",společně žily v dobré pověsti u sousedů po dobu 18 let." ${ }^{15}$

Příkladů dvou žen užívajících jazyka manželství k popisu svého vztahu $\mathrm{v}$ poměrně privátním kontextu deníků a dopisů je v 19. století velmi mnoho. Eleanor Butler ve svých denících mluví o milované Sarah Ponsonby jako o své „lepší polovičce“ [citováno v Incorvati 2001: 176]. Sochařka Harriet Hosmer, jedna z římských př́itelkyň Charlotte Cushman, nazývá ovdovělou Angličanku Lady Louisu Ashburton "moje sposa“ a samu sebe označuje za jejího "manžílka“, ,provdanou manželku“ a dceru. V dopise Ashburton o manželství mezi monarchy Hosmer dodává: „Budou ve svém manželském životě tak štastní jako jsme my v našem“, v jiném dopise slibuje: „až tu budeš, budu se chovat jako vzorná manželka (nebo manžel, jak budeš chtít)" [Sherwood 1991: 271; Markus 2000: 247; Vicinus 2004: 51, 50]. Už dříve v 19. století se Anne Lister a Anne Walker rozhodly, že se stanou

${ }^{13}$ Protože se specializovala na mužské role, byla Cushman mnohdy vnímána jako maskulinní; Matildě Hays, její milence před Emmou Stebbins, se často říkalo Max nebo Matthew [Merrill 1999: 160]. Také o jejich př́itelkyních Harriet Hosmer, Frances Power Cobbe a Rose Bonheur se často tvrdilo, že mají chlapecký nebo mužný vzhled. Merrill [1999: 125] dále uvádí, že kritici mnohdy komentovali mužnost Cushman jakožto herečky, ale tuto charakteristiku nespojovali s její sexualitou.

${ }^{14}$ Otevřené nepřátelství $\mathrm{k}$ transgenderovým ženám se objevuje $\mathrm{v}$ knize Sinks of London [1848: 66, 67], v níž jsou ženy oblékající se jako muži nazývány „Zvláštní bytostí" a „kreaturou“, jež „má manželku; a jako by toho nebylo dost ani pro muže, mají ještě navíc i milenku."

15 O ženách z 19. století oblékajících se nebo žijících jako muži viz van Slyke [1993], Townsend [1996], Wheelright [1989] a [Cross-dressing 2001]. 
„životními družkami“ ve vztahu, který podle obou „,bude tak dobrý jako manželství". Lister zpečetila svůj svazek s Walker tím, že jí darovala prsten a zařídila společné přijímání spolu s právním obřadem, v němž si obě navzájem odkázaly svůj nezatížený majetek [Liddington 1998: 62, 94]. Nekrolog v Anglii narozené Annie Hindle uveřejněný v roce 1892 v Chicago Herald sděluje, že roku 1886 byla tato slavná představitelka mužských rolí sezdána se svou "garderobiérkou a věrnou společnicí" Annie Ryan, „pětadvacetiletou pohlednou menší brunetou“ „,kazatelem Evangelia Reverendem E. H. Brooksem“, který „slavnostně prohlásil Annie Hindle za manžela Annie Ryan“. Hindle se vdávala v mužském oblečení a s mužským jménem, ale článek uvádí, že když po svatbě žila s Ryan, oblékala se jako žena: „Sousedé si jich vážili. ... Skutečnost, že mohly spolu žít otevřeně jako muž a žena, manžel vždy v ženském oblečení, a přitom nevyvolat žádné pohoršení, je nejlepším důkazem úcty, v níž je měli lidé v jejich okolí" [Chicago Herald, 27. prosince 1892 citováno v Hellerstein, Hume, Offen 1981: 188-9].

Idea ženského manželství nebyla pouhou soukromou metaforou užívanou ženami ve stejnopohlavních vztazích; byl to termín používaný také legálně oddanými k označování vztahů, jež byly otevřeně udržovány a neutrálně se o nich debatovalo ve vážené společnosti. Ani mezi příslušníky viktoriánských středních tříd nebyla manželství definována pouze zákonem a párům bez legálního statusu poskytovala sociální akceptace legitimizaci a zavedená pravidla pro začínání a ukončování vztahů. ${ }^{16}$ Charlotte Cushman předpokládala, že mnozí v jejím okolí o sexuálních poměrech mezi ženami vědí, nebot v roce $1860 \mathrm{v}$ jednom dopise Emmu Crow varovala, že "na tomto světě jsou lidé, kteří by mohli rozumět naší lásce, a proto je nutné, abychom si její projevy nechávaly pro sebe“ [citováno v Markus 2000: 65]. Historický kontext ponechává překvapivě nevyjasněnou otázku, zda se Cushman dožadovala diskrétnosti, protože Crow byla žena, nebo protože se bála toho, že bude odhaleno její cizoložství. Neexistují podobné záznamy dokládající, že by se Cushman snažila utajit také své vztahy s Elizou Cook, Matildou Hays nebo Emmou Stebbins, které byly nejen veřejným tajemstvím, ale dokonce se výslovně přiznávaly v jejím sociálním okruhu a v novinách. Cushman a její milenky vystavovaly své intimní vztahy všem na odiv. Ve 40 . letech 19 . století Cook uveřejnila vášnivou báseň "Charlottě Cushman", v níž se o obou ženách říká, že , jssou lapeny v nevolnictví Lásky“ [citováno v Merrill 1999: 138]. A když Hays roku 1851 vydala svůj překlad La Petite Fadette od George Sand, věnovala jej Charlottě Cushman. Během turné po severoamerických divadlech v roce 1849 Cushman cestovala společně s Hays a novinový článek velebící Cushman jako „ženu ... hodnou poct a vážnosti“ dodal: „Slečnu Cushman bude doprovázet její

\footnotetext{
${ }^{16}$ V knize Intimní prátelé se Martha Vicinus vyslovuje dvojznačně o sociálním statusu takových vztahů, jaký udržovaly kupříkladu Hosmer a Ashburton; na jednu stranu uvádí, že viktoriánům „nečinilo obtíže tolerovat rozvoj zvláštních sexuálních vztahů, dokud se o nich nezačalo otevřeně mluvit", ale na straně druhé "Cushman a Hosmer ... nikdy nepředstíraly, že nejsou ženami, které milují jiné ženy, a jako takové i byly přijímány“ [Vicinus 2004: 54, 55].
} 
přítelkyně, spisovatelka a překladatelka Matilda M. Hays." [citováno v Merrill 1999: 163]

Ve snaze najít slovník pro zachycení vztahů mezi ženami viktoriáni často čerpali z upraveného hyperbolického lexikonu přátelství, ale také na ženské páry aplikovali koncept manželství. V roce 1852 psala Elizabeth Barrett Browning své sestře Arabele o setkání s Matildou Hays a Charlotte Cushman toto: „Mám za to, že ona a slečna Hayes (sic) přijaly slib celibátu a věčné přináležitosti k sobě navzájem - žijí společně, oblékají se stejně ... je to ženské manželství. Náhodou jsem řekla, ,Aha, nikdy dřive jsem o něčem takovém neslyšela.' 'Ne?', řekla na to paní Corkrane (sic), ... ,ach, to není vủbec nic neobvyklého.' Jsou na cestě do Říma a tak si troufám říci, že se budeme často vídat. Ačkoli je to herečka, ... slečna Cushman má bezvadný charakter." [citováno v Browning 1951: 27, n. 12] ${ }^{17}$ Informátorkou Elizabeth Barret Browning byla manželka novináře Johna Frazera Corkrana, dopisovatele listu Morning Chronicle. Odkaz na slib celibátu by mohl naznačovat, že Browning ztotožňuje ženské manželství s rezignací na sexualitu, ale spojení ženského celibátu s „,věčnou přináležitostí" obou žen k sobě navzájem mění definici celibátu spíše na vzájemný slib nikdy se neopustit kvůli sňatku s mužem, což je jedna z možností, jak vyložit termín, který v citátu následuje, „ženské manželství". Ledabylost výroku "Náhodou jsem řekla“ nejde dohromady s důraznou povahou toho, co Browning říká - „Aha, nikdy dříve jsem o něčem takovém neslyšela", ale naznačuje její touhu dokázat, že už vstřebala lekci zdvořilosti, již dostala od své vdané spoluřečnice, která poznamenává, že "to není vůbec nic neobvyklého“. Závěrečná poznámka o dobré pověsti Charlotte Cushman nevytváří žádné pojítko, ani pozitivní, ani negativní, mezi jejím ženským manželstvím a „bezvadným charakterem“. Browning nenaznačuje, že se chce Cushman a Hays vyhýbat, ale právě naopak sděluje, že předpokládá, že se budou vídat často - což se skutečně stalo, a Browning mnohdy brala s sebou také svého manžela a jejich malého syna.

Pro porozumění sociálnímu postavení žen $\mathrm{v}$ ženských manželstvích je vhodné zavést rozlišení mezi subkulturou a sítí. Charlotte Cushman nepatřila $\mathrm{k}$ nějaké subkultuře, typu sociální skupiny, která je zpravidla uspořádána kolem omezeného počtu sdílených rysů a která drží pospolu díky oddělení od většinové společnosti. Byla však členkou sítě, formy sociálního spojenectví, jejíž síla se odvozuje od její relativní otevřenosti a vnitřní různorodosti a od jejích vazeb na jiné sítě. Sítě definují překrývající se množiny známostí stejně jako sdílené identity; čím silnější je sít, tím vyšší je počet a množství typů skupin, s nimiž je propojena. Sít Charlotte Cushman tak zahrnovala ženy žijící ve vztazích s jinými ženami nebo mající o takové vztahy zájem a dále měla mnoho vazeb na lidi, kteří nežili v párech osob stejného pohlaví. Její okruh se do značné míry překrýval například s okruhem kolem Elizabeth Barrett Browning, jenž se skládal z vysoce uznávaných umělců, kteří se usadili v Itálii, aby byli dále od své nejbližší rodiny, žili

17 Dar Roberta Browninga Kate Field zaznamenává Lilian Whiting [1911: 153-4]. O téměř každodenních stycích mezi Browningovými a Hosmer v roce 1857 viz Carr [1913: 92]. 
v teplejším podnebí a měli přístup k italské historické kultuře. Integrace Charlotte Cushman do mnoha sítí ukazuje, jak jednoduše bylo možné stejnopohlavní vztahy mezi ženami asimilovat s modelem manželství. Jak poznamenává Merrill, vztahy s Matildou Hays a Emmou Stebbins dokonce Cushman pomohly do řady sítí teprve proniknout, protože jí propưjčily auru solidnosti a úctyhodnosti (190).

Ženy žijící v ženských manželstvích nebo mající zájem o sexuální svazky se ženami se sdružovaly spolu navzájem, ale také vstupovaly do sociálních okruhů utvářených kolem legálně oddaných párů. Robert a Elizabeth Barrett Browningovi trávili čas nejen s Cushman a Hays, ale také s několika dalšími ženami, jejichž intenzivní stejnopohlavní vztahy zahrnovaly krátké flirty, bouřlivá poblouznění, krátkodobé aférky a dlouhodobá partnerství. Dopisy manželů Browningových připomínají řadu večeří, pikniků a výletů s Harriet Hosmer, Isou Blagden, Kate Field a Frances Power Cobbe, a krom toho také s Cushman a Stebbins. V některých př́ipadech byly tyto vazby hluboké: Blagden byla jedním z lidí, s nimiž si Robert Browning nejvíce dopisoval, Hosmer udělala slavný odlitek Browningových rukou a Kate Field věnoval Robert po smrti své ženy medailónek s řetízkem, který Elizabeth nosila od dětství, a přidal k němu pramen vlasů své manželky. ${ }^{18}$ Cushman, Hosmer a Cobbe dobře vycházely s vdanými ženami, jako byly Jane Carlyle, Mary Somerville a Margaret Oliphant, a často se stýkaly i s jejich manželi. Harriet Hosmer si osvojila chlapecký způsob oblékání a chování a otevřeně flirtovala se ženami, ale biografická literatura viktoriánské doby dokládá, že se s ní chtěly setkat desítky vážených Angličanek, které navštívily Rím. Znala se s Gladstonovými, se Sirem Williamem Boxallem (ředitelem Národní galerie a portrétistou předních osobností doby) a s Layardovými (Austen Layard byl archeolog, politik a velvyslanec v Madridu v 70. letech 19. století; jeho žena byla dcerou Sira Johna a Lady Charlotte Guestových). Koncem 60. let figurovaly mezi jejími návštěvnicemi manželka diplomata, křestanka věnující se dobročinnosti a Anne Thackeray, která do Říma přijela s paní de Rothschild [viz Carr 1913: 189; Somerville 1873: 305, 359]. ${ }^{19}$

V 60. a 70. letech 19. století, kdy sexuologická idea inverze ještě nebyla moc známá a mnozí lidé stále spojovali sodomii se sexuálními úkony naprosto odporujícími přírodě a ctnosti, byl ženský pár přijímán jako variace k právnímu manželství a nepovažoval se za samostatný druh partnerského spojení. To naznačuje, že Lillian Faderman a Carroll Smith-Rosenberg měly zcela pravdu v tom, že viktoriáni pokládali lásku mezi ženami za něco naprosto normálního, at' už

\footnotetext{
${ }^{18}$ Martha Somerville [1873: 326] uvádí, že Cobbe znal a měl v oblibě také pan Somerville. K př́ikladům Angličanek, které se zmiňují o tom, že se při návštěvě Říma setkaly s Hosmer (a také s Williamem Storym), viz Letters [1875: 11], Bloomfield [1883: 301-2, 310] a Ritchie [1924: 137].

${ }_{19}$ Martha Somerville [1873: 326] uvádí, že Cobbe znal a měl v oblibě také pan Somerville. K př́ikladům Angličanek, které se zmiňují o tom, že se při návštěvě Říma setkaly s Hosmer (a také s Williamem Storym), viz Letters [1875: 11], Bloomfield [1883: 301-2, 310] a Ritchie [1924: 137].
} 
jí byla intenzivní smyslná přátelství existující vedle manželství s muži (SmithRosenberg) nebo celoživotní partnerství, která manželství s muži nahrazovala (Faderman) [Smith-Rosenberg 1996; Faderman 1981]. Ale ukazuje se také, v čem se mýlily. Smith-Rosenberg chybně pojala intimitu mezi ženami jako doplněk k manželství mezi mužem a ženou, nebot ženy v ženských svazcích nehledaly doplnění manželství, ale manželství si přivlastnily. Faderman se mýlila v tvrzení, že akceptace ženských párů byla závislá na tom, jestli jejich vztahy byly vnímány jako asexuální; užití manželství jako termínu pro popis ženských párů ukazuje, že se mělo za to, že sex je ve hře, nebot manželství, na rozdíl od přátelství, nikdy nebylo asexuálním pojmem. Pro viktoriány manželství znamenalo spojení sexuálních a duchovních podnětů, smíření sexuality se solidností. Manželství bylo sociálně přijatelným předváděním sexuální intimity, protože se zakládalo na věrnosti, a odhalovalo tak nejen sexualitu partnerů, ale také to, že přijali jisté zábrany a limity. $Z$ tohoto důvodu ženské manželství nebylo spojováno s divokým stavem sexuální rozvolněnosti, ale naopak bylo snadno integrovatelné i do těch nepřísnějších představ o společenském pořádku. Jak však uvidíme, ženské manželství se také výrazně lišilo od právního manželství mezi muži a ženami a tyto rozdíly z něj udělaly vzor pro reformátory snažící se o modernizaci právního manželství.

\section{Ženské manželství a viktoriánská manželská reforma}

Až do roku 1857 bylo právní manželství v Anglii definováno svou praktickou nerozlučností, nebot' rozvod spojený s možností nového sňatku byl nanejvýš složitý a nákladný. Manželské právo také zakládalo formální nerovnost mezi manželi a manželkami, jelikož princip podřízenosti ženy manželovi (coverture) stanovil, že legálně tvořili jednu osobu, totiž manžela. Dủkladná reforma těchto zákonů začala v roce 1856, kdy Barbara Leigh Smith podala do Parlamentu petici, v níž požadovala změnu zákonů upravujících vlastnictví vdaných žen, jež zcela náleželo manželovi, pokud nebylo chráněno přirozeným právem. I když byl bezprostřední úspěch této petice jen částečný, pohnula politiky $\mathrm{k}$ tomu, aby v následujícím roce připravili zákon o občanském rozvodu. Ve snaze získat podporu žen, které nebyly vdané za muže, a mohly tedy být pokládány za nezainteresované stoupenkyně reforem, Smith usilovala o podpisy několika žen, které někdy v životě žily v ženských párech, včetně Isy Blagden, Geraldine Jewsbury, Amelie Edwards, Charlotte Cushman a Matildy Hays.

Skutečnost, že řada žen více se zajímajících o vztahy se ženami než o manželství s mužem podepsala petici požadující přijetí Zákona o vlastnictví vdaných žen, naznačuje afinitu mezi vztahy osob stejného pohlaví a manželskou reformou, již Smith nejspíše nemohla vytušit, a to takovou, která nemůže být jednoduše vysvětlena touhou feministek rozšíritit práva všech žen. Hays byla vždy feministkou, a zůstala jí i poté, co podepsala petici z roku 1856, ale její podpora rozvodu vycházela také z její zkušenosti s ženským manželstvím. Když v roce 1857 skončil 
její vztah s Cushman, Hays se vrátila do svého feministického kroužku v Londýně, kde se podílela na publikaci English Woman's Journal a vedení Společnosti pro rozvoj zaměstnanosti žen, a nakonec navázala nový vztah s vdovou Lady Theodosií Monson (k „Vášnivému př́telství“ mezi Hays a Monson viz [Holcombe 1983: 85; Anderson 1987: 63]. Živila se také jako překladatelka a spisovatelka a v jejím románu Adrienne Hope (1866) vystupují postavy vytvořené podle ní a Lady Monson - slečna Reay a její stálá společnice, starostlivá vdova Lady Morton. Slečna Reay přiznává, že podporuje práva žen, a pokračuje: „Až do velice nedávné doby byla vdaná žena pouze kusem majetku ... absolutně přináležejícím jejímu manželovi. ... Nový Rozvodový soud tento stav věcí napravil." [Hays 1866: 249-50] V jejím dřívějším románu Helen Stanley jedna z postav pronáší didaktickou řeč, v níž hájí názor, že rozvod je platným řešením problému neštastných manželství, a odvážně tvrdí, že milovat lze více než jednou [Hays 1846: 324]. Ve svém politickém a literárním díle Hays připravovala praktické a etické zázemí pro rozvod tím, že usilovala o posílení ekonomické soběstačnosti žen a odrážela stále se opakující obvinění, podle něhož rozvod dává posvěcení čistě tělesné promiskuitě.

Feministická vize zákonů, které by daly ženám legálně provdaným za muže více svobody, zahrnovala u Matildy Hays definici manželství, ke které dospěla, když navazovala a ukončovala své vlastní ženské manželství. I když ženy žijící v ženském manželství neměly výhodu legálně uznaného svazku, těšily se už dvěma privilegiím, za která ženy provdané za muže bojovaly po celé století: nezávislému právu na vlastní př́jem a vlastnictví a svobodě ukončit vztah a začít nový. Vytvářely také svazky, jejichž základy nebyly závislé na sexuální rozdílnosti, genderové hierarchii nebo biologické reprodukci, což byl naopak přinejmenším v právní teorii, když už ne v sociální realitě, případ většiny viktoriánských manželství mezi muži a ženami. Jako mnozí jiní stoupenci nových práv manželek na rozvod nebo vlastnictví Hays tvrdila, že manželství se může a má zakládat na rovnosti a podobnosti partnerů. „Smlouva“ byl termín shrnující názor, že legální manželství osob různého pohlaví má být rozlučitelné a má poskytovat rovnost a nezávislost manželkám - a "smlouva“ byl také výraz, který již vystihoval většinu ženských manželství. Anne Lister a Anne Walker využily závětí a smluv k formalizaci svého vztahu a Rosa Bonheur sepsala podrobné závěti se svou první i druhou partnerkou, Nathalií Micas a Annou Klumpke. Podobně jako nápadníci v heterosexuálních vztazích, u nichž se sexuální a romantická vášeň spojovala s ekonomickým kalkulem (vzpomeňme na vyjednávání doprovázející námluvy v Trollopových románech), ženy žijící v ženských manželstvích uzavíraly formální dohody, v nichž se vzájemná láska spojovala s finančními zájmy. Když Rosa Bonheur požádala Annu Klumpke, aby s ní žila, nejprve jí vřele vyznala lásku a poté napsala Annině matce dopis, v němž jí vysvětlila jejich rozhodnutí "spojit (svou) existenci“ a ujistila ji, že "dohodne u právníka takové uspořádání, aby (Anna - pozn. aut.) byla jako ve svém vlastním domě.“ [Whiting 1940: 47]

Ženy jako Bonheur a Klumpke budovaly své vztahy po vzoru romantického manželství definovaného láskou a věrností, ale přijaly také odvážně moderní 
pojetí manželství jakožto smlouvy. Radikální utopista William Thompson prohlašoval v roce 1825, že manželství ve skutečnosti smlouvou není, protože představuje nerovný a nerozlučný svazek, jehož podmínky stanoví stát [viz Taylor 1983]. V polovině 19. století se tato kritika objevila znovu v liberálních a feministických obhajobách reformy právního manželství mezi muži a ženami, mezi nimi i v takových, jež formulovaly ženy žijící v ženských manželstvích založených na smluvních zásadách. Smluvní manželství bylo ve srovnání s právním principem podřízenosti ženy manželovi rovnostářské, protože vycházelo z předpokladu vzájemně prospěšné směny, v níž byly zohledněny obě strany. V závěti Rosy Bonheur se sděluje, že odkazuje všechen svůj majetek Anně Klumpke, protože ji požádala, „aby bydlela se mnou a sdílela se mnou můj život" , a z toho důvodu se „rozhodla poskytnout jí kompenzaci a chránit její zájmy, protože obětovala postavení, které si již získala, aby mohla žít se mnou, a podílela se na nákladech údržby a zvelebení mého domu a nemovitostí" [Klumpke 1997: 264]. Nuceny okolnostmi vytvářet pro své vztahy improvizované legální rámce, ženy žijící v ženských manželstvích v 19. století byly nejen předchůdkyněmi "domácích partnerů stejného pohlaví" pozdního století dvacátého, ale také předjímaly formy manželství mezi muži a ženami institucionalizované až mnoho desetiletí po jejich smrti.

Ženy $\mathrm{v}$ ženských manželstvích se odvolávaly na smluvní principy při rozpouštění svých svazků stejně jako při jejich formalizaci. Vlastní akt ukončení svazku závisel na analogii mezi manželstvím a smlouvou. Oliver Wendell Holmes v pojednání The Common Law (1881) uvádí, že podstatou smlouvy je to, že každá strana má „svobodu smlouvu porušit, uzná-li to za vhodné“. Zákon lidi nenutí smlouvy dodržovat, ale pouze $\mathrm{k}$ tomu, aby platili odškodné za jejich neplnění [Holmes 1963: 236]. Když v roce 1857 po setkání Charlotte Cushman s Emmou Stebbins začal vztah Cushman s Matildou Hays skř́ipat, Hays pohrozila Cushman, že ji zažaluje o náhradu škody za to, že obětovala svou literární kariéru tomu, aby mohla s Cushman odjet do Itálie. Cushman se moc nesnažila udržet požadavek Matildy Hays v naprosté tajnosti; věděla o něm Harriet Hosmer a Anne Brewster, raná milenka a stálá př́telkyně Cushman, se o tom rozepisovala ve svém deníku. Požadavek Hays, aby jí Cushman vyplácela jakési alimenty, mohl být jemnou formou vydírání, ale to, čím Hays vyhrožovala, nebylo odkrytí vztahu už tak dost otevřeného, aby se o něm objevovaly zmínky v novinách a věděli o něm všichni v jejich společenském okruhu. Možnou rozbuškou skandálu bylo odhalení, že prŕíčinou jejich rozchodu byla nevěra Charlotte Cushman. Aby utišila zprávy o svém cizoložství a aby dala najevo, že uznává, že porušila jejich dohodu žít společně, Cushman zaplatila Hays tisíc nebo dva tisíce dolarů, v onu dobu značnou částku a také doklad toho, že podobně jako Hays chápala jejich svazek podle základního principu smlouvy: strana, která dohodu poruší, musí zaplatit odškodné [viz Merrill 1999: 185].

Ženská manželství se neobešla bez komplikací a nevěra, spory a mocenské rozdíly je sužovaly stejně jako legální manželství, ale jelikož stát nespojoval ženské páry na celý život, jejich svazky ztělesňovaly vlastnosti, které se britské aktivistky 
a aktivisté snažili zavést do manželství mezi muži a ženami: rozlučitelnost, relativní rovnostářství a více svobody pro oba partnery. To byly věci poměrně naléhavé: nauka o podřízenosti ženy manželovi stanovila, že manželčin příjem a vlastnictví nechráněné přirozeným právem a stejně tak i děti manželů patří výhradně manželovi. Až do roku 1891 mohl manžel podle zákona držet svou ženu proti její vůli v domácím vězení a neexistoval právní pojem manželského znásilnění.

V 50. letech 19. století se feministky usilující o odstranění podřízenosti ženy manželovi a získání nezávislých práv pro legálně sezdané ženy spojily s liberálními utilitaristy, kterým šlo o racionalizaci práva a přenesení autority z církve na stát. Společně navrhli zákon o vlastnictví podporovaný Hays a Cushman a pomohli k přijetí kontroverzního Zákona o rozvodu a manželských záležitostech z roku 1857, který tím, že přesunul jurisdikci od církevních soudů k prvnímu soudu pro občanské rozvody v zemi, učinil rozvod možností dostupnou mnohem většímu počtu lidí než kdykoli dříve [Shanley 1989, 1982; Woodhouse 1959; Stetson 1982; Holcombe 1983]. Avšak nový zákon neskoncoval s podřízeností ženy manželovi nebo hierarchickým manželstvím a kodifikoval dvojí standard, podle kterého bylo pro manželky obtížnější žádat o rozvod než pro muže. I tak se obecně mělo za to, že tento zákon omezuje moc a prestiž mužů. Soubor satirických kreseb otištěný v týdeníku Once a Week zobrazoval rozvodový soud jako místo, kde manželky okrádaly a šikanovaly své manžele, a časopis Englishwoman's Domestic Magazine v roce 1864 konstatoval, že „odhalení Rozvodového soudu ukazují, že existují špatní manželé stejně tak jako dobří“ [Divorce 1860; The Lady 1864: 209]. Statistiky naznačují, jaké byly skutečné účinky zákona: v letech 1801 až 1857, kdy rozvod ještě musel být potvrzen parlamentním dekretem, bylo uděleno pouze 190 povolení k rozvodu, zatímco v desetiletí 1858-1868 nový občanský soud vydal 1279 rozváděcích dekretů [Horstman 1985: 32, 85]. Zákon z roku 1857 nabízel zajímavý nový způsob ukončení manželství zvláště pro ženy: před jeho schválením získaly parlamentní dekret pouze čtyři ženy, ale v letech 1858 až 1868 manželky iniciovaly $40 \%$ žádostí o rozvod a v rozvádění manželství byly zhruba stejně úspěšné jako manželé [Savage 1992: 26].

Zákon z roku 1857 měl kulturní důsledky, které daleko překračují jeho právní význam. Jak poznamenala v roce 1866 Bessie Rayner Parkes, „přijetí nového rozvodového zákona doprovázela ... univerzální diskuse o prvních principech“ [Parkes 1866: 445]. Abstraktní debaty o manželství jakožto instituci provázel nový hlad veřejnosti po senzačních zprávách o rozpadech manželství. Povolení k rozvodu dostaly stovky dvojic, ale rozvodová řízení sledovaly tisíce čtenářù a novinové zprávy o jednání před rozvodovým soudem odhalovaly různorodost manželství jako žité instituce [Leckie 1999: 68; Fahnestock 1981]. Široká veřejnost se ve zprávách ze soudní síně dozvídala, že součástí manželského života v Británii mưže být násilí, cizoložství, incestní cizoložství, bigamie a dokonce i sex mezi ženami (téma ve dvou známých rozvodových procesech, případu Codrington z roku 1864 a případu Dilke-Crawford z roku 1885). Také záplava románů o bigamii, cizoložství a rozvodech vydaných vesměs mezi lety 1857 a 1865 uspokojovala hlad po přibězích o manželstvích porušujících zavedená pravidla. Volání 
po cenzuře zpráv o rozvodových řízeních $\mathrm{v}$ zájmu ochrany soukromí a veřejné mravnosti nebylo účinné. Jeden ze zastánců cenzury, W. E. H. Lecky, byl také autorem populárních dějin morálky, v nichž stavěl evropskou civilizaci pro její křestáanské pojetí celoživotní monogamie na vrchol lidského vývoje. Jeho výzvy, aby nebyly publikovány popisy rozvodových líčení, naznačují, že si uvědomoval, jak jasně odhalovaly rozpor mezi skutečnou praxí manželských dvojic a tím, co kázaly zákony o manželství. ${ }^{20}$

Rozvodový zákon z roku 1857 také změnil podmínky celibátu a vedl k velké diskusi v novinách o tom, zda je manželství vůbec nutné, zejména ve světle údajů ze sčítání lidu, jež ukazovaly na stále větší počet mužů a žen, kteří se nikdy neožení a nevdají. Viktoriánské feministky tvrdily, že společenský nátlak na uzavření manželství upevňuje mužskou nadvládu, nebot ženy vstupují do manželství, v němž jim připadá podřízené postavení, jen proto, že nesezdaný stav by pro ně znamenal ekonomickou závislost a společenskou smrt. Pozorovatelé, kteří se domnívali, že jediným vhodným údělem ženy je stát se závislou manželkou, udělali předmětem své lítosti neprovdanou „starou pannu“: „Svobodná žena! Není v těchto dvou vedle sebe stojících slovech cosi žalostného? Žádná žena není svobodná z vlastní volby“" [Greenwell 1862: 63, 64]. Jiní autoři popisovali svobodný stav jako něco nepřirozeného: „V přírodě neexistuje nic samotného; s celibátem se při stvoření nepočítalo" [Old Maids 1860: 709]. Feminista John Stuart Mill odporoval tezí, že v důsledku takových stereotypů je touha provdat se ve skutečnosti jen výrazem odporu proti stigmatu plynoucímu z neprovdanosti, nebot ",svobodná žena ... se pokládá sama i je pokládána druhými za jakýsi výrůstek na povrchu společnosti bez využití, funkce nebo úlohy“ [Mill 1970a: 72, 77]. Feministky tvrdily, že pokud má v manželství mezi mužem a ženou vládnout rovnost, pak také svobodné ženy musí mít možnost žít prakticky zvládnutelným a uspokojivým životem. Volání po reformě manželství začalo jako snaha o to, aby v něm byla rovnost a stalo se pružnějším, a posléze se vyvinulo v požadavek, aby manželství nebylo povinností. Změna kvality života nesezdaných by proměnila i samotné manželství.

Zatímco někteří autoři upozorňovali na obtíže, s nimiž se musely neprovdané ženy utkávat, jiní tvrdili, že život neprovdaných žen už je snadnějšśí, než si mnozí myslí, a že manželství už není pro ženy jediným žádoucím osudem. V 60. letech 19. století si neprovdané ženy získaly viditelnost jako aktivistky, filantropky a umělkyně, jejich úsilí jim vydobylo místo ve společnosti, prostupnější díky všeobecnému dưrazu na reformu. Skvělé výkony během krymské války svobodným ženám vysloužily více uznání u veřejnosti. Imperialistická rétorika požadující, aby Anglie doma naplňovala své hodnoty demokracie a rovnosti, aby je mohla lépe šřřit v zahraničí, napomohla rostoucímu ocenění společenského přínosu všech žen. Feministka Caroline Cornwallis v roce 1857 varovala čtenáře, že „Svázat ruce jedné polovině lidstva ... je sebevražedným aktem nehodným náro-

${ }^{20}$ Leckie [1999: 97] upozorňuje na Leckyho výzvu, aby zpravodajství od rozvodového soudu bylo cenzurováno. 
da, jejž si všemohoucí vůle zřejmě vyhlédla jako velikého civilizátora celého světa“ [Cornwallis 1857: 43]. Během 60. let se psaní o svobodných ženách stalo dostatečně rozšířeným trendem, aby jeden knižní recenzent mohl poznamenat: „Spočívá-li bezpečí v množství rádců, jak požehnaná musí být bezpečnost svobodných žen!“ Poté co ze svobodných žen udělal bytosti závislé na vedení "množstvím rádců“, recenzent dospěl k závěru, že manželství je tím nejlepším stavem, nebot' "(m)už a žena musí být Jedno." I on však připustil, že ženy bez manžela potřebují práci jako oblast uplatnění jejich talentu [Greenwell 1862: 62, 65, 77]. Jiní autoři se domnívali, že svobodný život může být pro ženy výhodnější, zejména s ohledem na manželská trápení, jež se dostala na veřejnost prostřednictvím zápisů z rozvodových řízení. Anne Thackeray poznamenala ve svém eseji „Nádenice a staré panny“ (1858), že svobodná žena „určitě nezávidí ubohé paní C., která musí utéct k Siru Cresswellu Cresswellovi (soudci rozvodového soudu - pozn. aut.), aby se zbavila ,životního společníka', který ji mlátí deštníkem, rozhazuje její peníze a sráží ji dolů, místo aby ji ,pozvedával“" [Thackeray Ritchie 1876: 5].

I vášniví obhájci manželství nepřátelští $\mathrm{k}$ feminismu začali připouštět, že některé ženy se nikdy neprovdají. Jako příklad si vezměme nejslavnější viktoriánský článek o svobodných ženách nazvaný „Proč jsou ženy nadbytečné?“ (1862) od W. R. Grega [Greg 1873]. ${ }^{21}$ Gregův článek je často uváděn jako doklad pohrdání, které viktoriánská éra chovala vưči neprovdaným ženám, protože jakožto silný zastánce manželství požadoval, aby „,nadbytečné“ Angličanky, které si nemohou najít manžela, byly vystěhovány do kolonií, kde počet mužů převyšoval počet žen. Ale Gregův text dokládá také rostoucí akceptaci svobodných žen. I když prohlašoval, že každá žena schopná spárování s mužem má být s nějakým mužem spárována, měl za to, že svobodné ženy jsou stejně přirozeným jevem jako monogamie, protože dospělých žen bylo více než dospělých mužů. Příroda stanoví, že „manželství, svazek jednoho muže s jednou ženou, je zcela jasně ... despotickým zákonem životním,“ ale př́roda „nejen vyhlašuje pravidlo, ale také zřetelně určuje přesný rozsah a meze výjimky" (279). Greg přirozenou výjimku kvantifikoval pomocí údajů ze sčítání lidu, podle nichž na 100 mužů ve věku nad 20 let připadalo 106 stejně starých žen. Děsivou anomálii pro něj představovalo zjištění z cenzu, že neprovdaných bylo 30 procent žen nad 20 let. Naproti tomu „,nadbytečných šest procent, pro něž neexistují rovnocenní muži," (282) Greg pokládal za normální výjimku jsoucí v souladu se „zcela přirozeným, zdravým a uspokojivým stavem společnosti“ (282) a úměrnou „přesnému procentuálnímu podílu žen, jež Příroda předurčila ke svobodnému životu“ (279). Svobodná žena byla pro Grega něčím tak přirozeným, že i samu Př́rodu personifikoval jako svobodnou ženu, která pilně sestavuje své plány a bez vedení manžela stanoví „despotický zákon životní“.

Greg kritizoval skutečnost, že počet neprovdaných žen v Anglii rostl, ale také určil pevně daný počet žen, pro něž byl celibát povinný. Tyto ženy defino-

${ }^{21}$ Všechny další odkazy na tento článek se vztahují ke zde citovanému vydání a jsou uvedeny $\mathrm{v}$ závorce přímo $\mathrm{v}$ textu. 
val jako „přirozené anomálie“, které postrádaly ženskost, milovaly nezávislost, chtěly sloužit lidstvu nebo byly "téměř hermafroditní díky svému géniu a moci: „Tyto jsou po právu a přirozeně svobodné; ale jsou to abnormální a nedokonalé povahy" (280). Abnormální je nedokonalé, ale rovněž přirozené, a Greg tak vlastně říkal, že neprovdané ženy (nikoli však nesezdaní muži) jsou něčím nevyhnutelným a ze společenského hlediska i nutným. Navzdory svému vehementnímu prosazování manželství také nezaujatě poznamenal, že některé ženy ",se záměrně rozhodují pro celibát jakožto pro věc, kterou chtějí pro ni samotnou“" (281). V jedné poznámce pod čarou Greg dokonce naznačil, že pro mnoho žen je svobodný život štastnější volbou: „V tisících př́ípadů jsou (svobodné dámy - pozn. aut.) po nějaké době štastnější (než manželky a matky - pozn. aut.). Když v našem věku dáma vlastní aspoň velmi skromný majetek a má dobře vybavenou a spořádanou mysl, může mít nekonečně méně starostí a nekonečně více potěšení, než pokud si vytáhla některý z mnoha prázdných losů, které znehodnocují loterii manželství" (299). Uznání, že svobodný život je něčím přirozeným, u Grega proměnilo manželství z osudové nutnosti v loterii, hazardní hru, jejíchž rizik se ženy mohou chtít na základě racionálního rozhodnutí vyvarovat.

Měnící se obraz svobodných žen byl dokladem rašení nových představ o manželství. Autoři 60 . let 19. století nacházející se v různých částech politického a rétorického spektra dokumentují rostoucí uvědomění, že manželství mezi mužem a ženou není univerzálním prvkem společenského života. V článku „Jak máme naložit s našimi starými pannami?“" (1862) využila Frances Power Cobbe [1996] stejných statistických údajů jako Greg k tomu, aby ukázala, že svobodné ženy se stávaly prvkem utvářejícím a současně proměňujícím společenskou krajinu Anglie. Cobbe a jiné autorky a autoři tvrdili, že svobodné ženy jsou štastnější než kdykoli dř́ive v minulosti, a že budou-li se neprovdané ženy těšit dobrému životu, promění se i samo manželství. Názor, že lidé mohou přežít nezávisle na manželství, také podrýval představu o manželství jako spojení osob opačného pohlaví, z nichž každá potřebuje tu druhou, aby vyplnila svůj nedostatek, a ladil s moderním pojetím družného manželství založeného na podobnosti a přátelství. Feminista John Stuart Mill, který byl jedním z mnoha osobních známých Cobbe, odrážel její pocity, když v Poddanství žen (1869) napsal, že "podobnost", nikoli rozdílnost, má být základem pravých svazků a manželství má být utvářeno po vzoru toho, "co se často děje mezi dvěma práteli stejného pohlaví“" [Mill 1970b: 233].

Pokud bylo manželství definováno láskou a utvářeno po vzoru přátelství mezi osobami stejného pohlaví, pak to, co se odehrávalo mezi dvěma práteli stejného pohlaví, se také dalo považovat za manželství. Ve svém eseji „Celibát versus manželství“ z roku 1862 Frances Power Cobbe napsala, že ženy, které se neprovdaly za muže, mohou dosáhnout štěstí, když navážou „opravdová něžná př́átelství“; celibátní žena se nemusí bát ",osamělého stáři“", nebot' si může snadno „najít ženu ochotnou sdílet s ní" život [Cobbe 1862: 233]. V pozdějších přednáškách Povinnosti žen Cobbe uvažovala takto: „Domnívám se, že každému ... musí být 
dána příležitost utvořit opravdové manželství s člověkem opačného pohlaví nebo jinak opravdové přátelství s člověkem stejného pohlaví a že bychom se na taková manželství a přátelství měli dívat jako na největší radost s slávu smrtelného života - svazky, do nichž můžeme ponořit celé naše srdce“ [Cobbe 1881: 169-70]. Cobbe nenápadně mění používané spojky z "manželství ... nebo ... přátelství" na „manželství a prátelstvi“" (zoýrazn. aut.), čímž manželství a přátelství proměňuje ze vzájemně se vylučujících alternativ na zaměnitelná pouta, u nichž má pohlaví partnerů malý význam pro kvalitu svazku.

Triumf družného manželství jako ideálu změnil nejen vztah mezi manželem a manželkou, ale také proměnil status nesezdaných lidí a poskytl půdu pro docenění svazků mezi osobami stejného pohlaví. Přesvědčení, že je lepší bez lásky manželství neuzavírat, dělalo z osob, které se odmítaly ženit nebo vdávat z praktických důvodů, duchovně nadřazené bytosti. Cobbe tvrdila, že ženy se budou vdávat z lásky, pouze pokud bude svobodný stav "tak svobodný a štastný, že (ženy - pozn. aut.) nebudou čelit žádnému pokušení na něm cokoli měnit krom jediného pokušení, jež by je mělo ovlivňovat - totiž lásky“" [Cobbe 1996: 239]. Ve své argumentaci chytře rámovala své odmítání povinné heterosexuality jako touhu po zlepšení manželství a vyzývala stoupence ctnostného manželství, aby podporovali právo neprovdaných žen na štěstí. Cobbe také implicitně mobilizovala všechny, kdo věřili, že manželství může ratifikovat každý svazek založený na náklonnosti. Mohla přitom mít před očima spojení, v jakém žila ona sama. Ač se nikdy legálně neprovdala, žila více než třicet let se ženou, jíž veřejně ř́íkala „,milovaná př́telkyně“", sochařkou Mary Lloyd [Cobbe 1894: 645].

Život Frances Power Cobbe je př́kladem toho, jak sociální sítě a neformální mimoprávní vztahy ovlivňovaly politiku a právo. Protože ženské manželství nebylo marginální tajnou praxí omezující se na nějakou subkulturu, ale bylo integrováno do velmi rozvinutých otevřených sítí, ženy jako Cobbe mohly utvářet své vztahy po vzoru smluvního ideálu manželství a požadovat, aby se právní manželství přetvořilo $\mathrm{k}$ obrazu jejich vlastních svazkủ. Cobbe byla členkou sítě feministických aktivistek a aktivistů bojujících za manželskou reformu, kam patřili také John Stuart Mill, Barbara Leigh Smith, Charlotte Cushman a Geraldine Jewsbury. Náležela také do širší sítě politiků, filantropů a novinářư zahrnující Waltera Bagehota, Matthewa Arnolda, lorda Shaftesburyho, kardinála Manninga a Lady Battersea, která ve svých memoárech okomentovala její krátké vlasy a nekonveční oblečení, ale také ji charakterizovala jako ,jednoho z mých nejváženějších přátel“ [Cobbe 1904: 456, 468-9, 478; Battersea 1922: 256, 222-3]. Cobbe se přátelila dokonce i s W.R. Gregem, svým protivníkem z debaty o neprovdaných ženách. ${ }^{22}$ Svými texty a profesionálními i osobními kontakty Cobbe dokázala ovlivňovat legislativu a veřejnou politiku. Její článek o „Mučení manželek v Anglii“ (1878) byl podnětem $\mathrm{k}$ přijetí zákonů usnadňujících chudým ženám získání příkazu

\footnotetext{
${ }^{22}$ Cobbe se o těchto známostech zmiňuje a cituje z dopisů s nimi ve svém vlastním životopise. O kontaktech s Gregem viz [Cobbe 1904: 469, 471-2]; s Johnem Stuartem Millem [op. cit.: 415]. K rozsáhlým sociálním sítím, k nimž Cobbe náležela, viz také Mitchell [2004].
} 
k odluce od manželů usvědčených z jejich napadení [Cobbe 1878]. Toho všeho dosáhla, když přitom otevřeně žila s jinou ženou ve vztahu, který ona i druzí považovali za odvozený od modelu manželství. Důležitá role, již Cobbe sehrála ve viktoriánských diskusích o celibátu, manželské reformě, domácím násilí a ženské práci, je dalším dokladem vlivu ženského manželství na proměnu forem manželství mezi muži a ženami. I když Cobbe sama nemohla hlasovat a s Mary Lloyd byla právně svázána pouze individuálními dohodami typu závěti, její psaní pro veřejnou sféru a její výborné postavení ve velmi rozvětveném sociálním světě napomohly právní a politické změně.

Výměna mezi ženskými páry a právní institucí manželství proudila ve dvou směrech. Jelikož se vztahy ženských párů chápaly jako manželství, poskytovaly modely pro pružnější, rovnostářštější a dobrovolná manželství mezi muži a ženami. Na druhé straně tlak na změnu zákonů upravujících manželství mezi muži a ženami ukazoval, že instituce manželství byla už docela tvárná, a dala se natrvalo vměstnat do nové formy bez zlomů a přerušení. $V$ důsledku toho ženské páry a jejich přátelé považovali za možné užívat pro popis těchto vztahů jazyka manželství. Anglická společnost 50. a 60. let 19. století nepřistupovala k ženským manželstvím jako k něčemu nebezpečnému, o čem se nesmí mluvit, a to přesto, že šlo o dobu, kdy většina lidí považovala sodomii za sexuální akt zcela v rozporu s přírodou nebo ctností. Ženské dvojice nepředstavovaly nějaký odlišný druh, ale spíše středostavovskou obdobu bigamistických párů z dělnické třídy, jejichž spojení byla nelegální, ale přitom se řídila neformálními pravidly, vyznačovala se jistou podobou svatebního obřadu a těšila se uznání osob páru blízkých, které věděly, že alespoň jeden člen dvojice byl právně sezdán s někým jiným [Frost 1997: 286, 294, 295]. Manželství nebyla definována pouze právně a pro páry bez legálního statusu nahrazovala právo jako legitimizující znak manželství sociální akceptace. Viktoriáni užívající pro ženské dvojice výrazů jako „manželka“ nebo „manželství“ je akceptovali jako variaci k právně sezdaným párům, a tak svazkům osob stejného pohlaví propůjčovali určitou ctihodnost. ${ }^{23}$ Přitom označování dvou žen za vdané dělalo $\mathrm{z}$ manželství, údajně stabilní základny každého srovnání, formu dostatečně ohebnou na to, aby se do ní vešel i ženský pár.

Společného jmenovatele mezi ženským manželstvím a reformovaným manželstvím mezi muži a ženami představovaly smluvní prvky rovnosti a rozlučitelnosti. Diskuse o Zákonu o manželských záležitostech z roku 1857 se týkaly otázky, zda manželství má být smlouvou, a pokud je smlouvou, pak co to znamená. Stoupenci větší rovnosti mezi manželkami a manželi obvykle byli pro chápání manželství jako smlouvy. Podle viktoriánských feministů typu Johna Stuarta Milla nebo Mony Caird je hlavním znakem smluvního manželství jeho rozlučitelnost, protože představuje právně nutný prvek každé smlouvy a zahrnuje v sobě myšlenky svobodného souhlasu a rovnosti. Příznivci tradičního hierarchického manželství naproti tomu zdůrazňovali, že manželství je definováno sexuální

${ }^{23}$ K soudobému vztahu mezi manželskými zvyklostmi a právními definicemi manželského svazku viz Borneman [1996: 230]. 
rozdílností a má transcendentní a nevratnou povahu, jakou smlouvy zpravidla nemají. Jediným tvrzením, na kterém se obě strany mohly shodnout, tak bylo to, že smluvní manželství je nutné chápat $\mathrm{v}$ termínech vyprávění o civilizaci jakožto pokroku, v němž sociální organizace sexuálních vztahů slouží k odlišení primitivních společností od moderních.

\section{Viktoriánská antropologie a dějiny manželství}

Viktoriáni se lišili v názorech na to, jestli smluvní manželství je projevem civilizace, nebo divošství a jestli civilizovanosti už bylo dosaženo, nebo je teprve nutné k ní dospět, ale dokonce i myslitelé tak odlišní jako Mill a Lecky se shodovali na tom, že je možné vést dělicí čáru mezi primitivním a moderním a že modernita je tím vyšším stupněm. Imperiální mocnosti 19. století rozdělily společnosti do stadií, přičemž křestáanství a Západ ztotožnily s vrcholem lidského vývoje a na ostatní náboženství a regiony pohlížely spatra, protože údajně uvízly v primitivní minulosti. Tento modus myšlení se často označuje za antropologický, nebot́ mnozí autoři 19. století, kteří začali jako první srovnávat kulturní a společenské formy, předkládali svá zjištění jako vyprávění mapující vývoj od jednoho souboru zvyků a zákonů k druhému. Jedna škola antropologie 19. století se snažila dodat rodícímu se oboru více vědeckosti měřením rasových rozdílů, zatímco jiná škola nabízela teoretické výklady jazyka, mýtu, práva, náboženství a příbuzenství. ${ }^{24}$ Autoři vyprávění o počátcích kultury, společnosti a státu zkoumali symbolické systémy, náboženské myšlení, politické struktury a ekonomickou směnu. Ve svých spekulativních dějinách rozlišovali mezi primitivními společnostmi, založenými na mýtu, síle, zotročení, neměnném statusu a klanové vládě, a společnostmi moderními, stojícími na rozumu, rovnosti, slibech, souhlasu, vládě práva a státních útvarech odlišných od př́buzenských vazeb.

Tou měrou, jak manželství ve viktoriánské současnosti procházelo hlubokými proměnami, různí autoři začali spekulovat o tom, jaké formy mělo v minulosti, a mnozí antropologové, kteří psali komparativní historie př́íbuzenství, si položili otázku, jíž jsme začali: má manželství dějiny? V 60. letech 19. století vydali své velké studie o zvycích týkajících se manželství a příbuzenství Henry Sumner Maine, Johann Bachofen, Lewis Morgan a John McLennan. Bedřicha Engelse tento fakt přiměl v knize Pưvod rodiny, soukromého vlastnictví a státu (1884) ke komentáři, že „(a)ž do počátku šedesátých let nemůže být o dějinách rodiny ani řeči“ [Engels 1972: 74]. Časová shoda rozvodové reformy s rozvojem zkoumání rodiny je jedním $z$ důvodů, proč se někteří badatelé domnívají, že mezi zákonem o manželských záležitostech z roku 1857 a ranou antropologií existuje souvislost, ale antropologie a reforma manželského zákona byly spojeny i různými pozoru-

${ }^{24} \mathrm{~K}$ antropologii v Anglii viz Stocking [1987] a Kuper [1988]. Časopis Anthropological Review, který začal vycházet $\mathrm{v}$ roce 1863 , obsahuje početné doklady o tom, že se mnoho britských antropologů zaměřovalo na měření rozdílů mezi rasami. 
hodně konkrétními způsoby. Sir James Wilde, pozdější Lord Penzance, byl současně soudcem rozvodového soudu a členem Antropologické společnosti [Sigel 2002: 50, 52, 53, 57]. Řada autorů dnes označovaných za viktoriánské antropology měla právnické vzdělání a jejich zaměření na výzkum manželství a příbuzenství v mezikulturní perspektivě vycházelo z jejich zájmu o současné právní kodexy. Henry Maine (1822-1888) započal svou kariéru jako profesor regius občanského práva na Cambridge a po roce 1861 byl pravoplatným členem indické Místokrálovské rady. Jeho práce z komparativní právní vědy ovlivnila rané antropologické a sociologické teoretiky definicí práva jako formy sociálního vyjádření a zkoumáním jeho časového vývoje [Maine 1963]. ${ }^{25}$ Johann Bachofen (1815-1887) byl švýcarský právník a historik římského práva a Lewis Morgan (1818-1881) studoval a praktikoval právo podobně jako John McLennan (1827-1881), který svou studii o Primitioním manželstuí (1865) označil za součást svého díla o „raných dějinách občanské společnosti“" [McLennan 1865: v]. ${ }^{26}$ Všichni tito autoři se zajímali o spojitosti mezi minulými a dnešními zákony. Maine se domníval, že právní kodexy obsahují mnoho archaismů, které přežívají, ačkoli jim odpovídající sociální formace už dávno neexistují, a tvrdil, že tyto přežitky minulosti v sobě skrývají klíc $\mathrm{k}$ její rekonstrukci. McLennan se zaměřoval na primordiální minulost předcházející psanému právu, ale také měl za to, že „právní symboly“ současnosti poskytují vodítko pro porozumění minulosti (12).

Krom ovlivnění proměnami manželství v soudobé společnosti antropologové podléhali také silnému vlivu Darwinova spisu O pưvodu druhů (1859) s jeho důrazem na variaci a evoluci. ${ }^{27}$ Tato Darwinova práce se nezabývala variacemi v sexuálním instinktu a jeho studie o sexu Původ člověka líčila lidskou sexualitu jako uniformně heterosexuální. ${ }^{28}$ Ale v Původu druhů je obsažena teorie vývoje jako plynutí a sama př́roda je definována představou o postupných variacích, přičemž reprodukční systém se chápe jako zdroj individualizujících změn a nikoli jako mechanismus pro identickou replikaci. Podle Darwina je identita každého druhu pomíjivá, neboť různé druhy mají společný původ v minulosti a „žádný žijící druh nepřenese svou nepozměněnou podobu do vzdálené budoucnosti“ [Darwin 1985: 73, 441, 90, 101, 456, 459]. ${ }^{29}$ Dokonce i zrůdy - „značná odchylka

\footnotetext{
${ }^{25}$ K Mainovu vlivu na několik generací antropologů viz Firth [1963: xxix-xxx] a Stocking [1987: 117].

${ }_{26}$ Všechny další odkazy na tuto knihu se vztahují ke zde citovanému vydání a jsou uvedeny v závorce přímo v textu.

${ }^{27}$ K Darwinovu vlivu na viktoriánskou antropologii viz Stocking [1987: 145-85]. Stocking nepokládá Maina za darwinistu [op. cit.: 168], ale Holcombe [1983: 5] mluví o Starověkém právu jako o př́ikladu „,darwinismu ... aplikovaného na zkoumání práva“.

${ }_{28}$ K tvrzení, že kniha O pưvodu člověka odráží Darwinův zájem o „sexuálně rozrůzněnou říši přírody“, viz Kaye [2002: 84-117]. Kaye říká, že tato stránka Darwinova myšlení z něj dělá autora důležitého, i když často přehlíženého příspěvku k dějinám touhy mezi osobami stejného pohlaví.

${ }^{29}$ Všechny další odkazy na tuto knihu se vztahují ke zde citovanému vydání a jsou uvedeny v závorce přímo v textu. Gillian Beer [2000: xviii, 13, 59, 97] se zabývá Darwinovým
} 
struktury v jedné části“ - se nacházejí na jednom kontinuu společně s variacemi podstatnými pro přírodní výběr a není možné je "od pouhých variací oddělit jasnou dělící čarou" (101, 72). Studie O piovodu druhů tak nabízela způsob uvažování o změnách $\mathrm{v}$ čase, $\mathrm{v}$ němž společné prvky a rozdíly byly navzájem provázány. Když Darwin na známém místě napsal, že „naše klasifikace se stanou ... genealogiemi“", myslel tím, že jsou-li druhy zkoumány v čase, je nutné zkoumat jejich společný původ i jejich neustálé transmutace (456). V knize Starověké právo (1861) Maine uplatnil darwinovský přístup na dějiny manželství a tvrdil o nich, že postupují vpřed podle dvou os historických změn: právní a sociální, v obou př́ipadech různou rychlostí. Současné společenské mínění bylo „Vždy více nebo méně napřed před právem“ a právní fikce, přirozené právo a přijímání nových zákonů byly nezbytné kvůli sladění zákonů se sociální praxí (23).

Pod Darwinovým vlivem antropologové v monogamním manželství spatřovali pouze jednu variaci mezi mnoha jinými. Na začátku tohoto článku jsem citovala př́́klady dobového spojování homosexuality s fantaziemi o primitivním chaosu - incestem, promiskuitou, polygamií. Viktoriánští antropologové sice tyto fantazie sexuálního divošství pomáhali vymýšlet, ale mnozí z nich také hlásali, že mezi ranými a moderními společnostmi existuje kontinuita, a přitom dovozovali i to, že neexistuje žádná pevně daná přirozená forma manželského práva. ${ }^{30}$ Darwinovská představa, že život je variabilní, vedla k názoru, že také právo a společenské zvyky jsou přizpůsobivé a tvárné. Antropologové, kteří pracovali na spekulativních dějinách manželství, často nacházeli důvěrné souvislosti mezi křestáanskou Evropou a primitivní minulostí, a divošským zvykům minulosti tak propưjčovali prestiž počátků. McLennan ve své studii Primitioní manželství napsal, že promiskuita je "nejstarší formou př́ibuzenství“ (160) a formy manželství pokládané v Anglii 19. století za barbarské, jako třeba polyandrii, ,je třeba přijmout jako stadium vývoje směrem k vlastnímu manželství a patriarchálnímu systému“ (225). ${ }^{31}$ Bachofenova práce Mateřské právo oponovala historikům odmítajícím teorii, že "nižší neregulované sexuální vztahy“ předcházely manželství, a varovala, že „nemilé překvapení čeká na ty, kdo v manželství vidí nutný

"důrazem na nepodobnost, transformaci a příbuzenství", jeho zájmem o „hojnost", „,variaci“ a odchylku a jeho vlivem na viktoriánskou antropologii.

${ }^{30}$ I když někteří badatelé tvrdí, že antropologie byla reakcí proti právním reformám napomáhajícím zrovnoprávnění mezi manželi a manželkami, jiní naopak nacházejí mezi reformátory a antropology kontinuitu. Elizabeth Fee a Lazar Barkan uvádějí, že antropologické texty potíraly feminismus tím, že zlomyslně spojovaly manželskou reformu s návratem do stavu primitivní promiskuity. Kathy Psomiades se domnívá, že antropologie znovuobjevila heterosexualitu v době, kdy se význam rozdílů mezi pohlavími začal oslabovat. George Stocking nachází kontinuitu mezi reformátory 50 . let 19 . století, kteří se snažili přimět viktoriány $\mathrm{k}$ tomu, aby si manželství začali představovat jinak než dosud, a antropology 60. let, kteří zkoumali různorodost manželských zvyků a př́buzenských systémů [viz Fee 1974: 87, 89, 100; Barkan 1995: 62; Psomiades 1999: 94; Stocking 1987: 207].

${ }^{31}$ Lubbock a Morgan také definovali nejstarší fázi vývoje rodiny jako společné manželství, v němž je každý partnerem každého [Lubbock 1978: 67]. 
prvotní stav“ [Bachofen 1967: 94].32 V práci o skupinovém manželství Kamilarojové a Kurnajové (1880) Lorimer Fison a Alfred Howitt tvrdili, že „některé důležitější instituce civilizovaných států je nutno hledat $\mathrm{v}$ jejich rudimentární podobě právě v tomto stavu divošství, z něhož pocházejí." V diagramu, který používal typicky anglická jména John, Jane, Smith a Brown ke znázornění vzorců příbuzenství u Turanů a Ganowanů, autoři dokonce naznačovali, že primitivní a civilizované manželské systémy jsou zaměnitelné [Fison, Howitt 1880: 102, 96]. Edith Simcox, profesionální spisovatelka a odborová aktivistka, a současně neúspěšná ctitelka George Eliot, prohlašovala v učené studii Primitivní civilizace (1894), že žádnou stránku „moderního rodinného života ... nelze vyzdvihnout jako tak výrazně a absolutně přirozenou, aby byla univerzální" [Simcox 1894: 9]. Simcox tvrdila, že primitivní civilizace je nejenom stejně přirozená jako moderní život, ale v některých ohledech mu je dokonce nadřazená. Když dokazovala, že v minulosti manželky vlastnily majetek, měly právo na své děti a těšily se právní autonomii, Simcox implicitně poukazovala na to, že manželky mohou požívat téže nezávislosti i v současné době, aniž by to jakkoli narušovalo tkáň společnosti [1.c.]. ${ }^{33}$

Pakliže primitivní společnost vznikla s incestem, pokrevním manželstvím, promiskuitou, komunálním manželstvím, infanticidou a polygamií, pak nebylo možné prohlašovat incestní tabu za univerzální a nedalo se tvrdit, že nerozlučné, monogamní a hierarchické manželství je fundamentální pro lidskou přirozenost nebo lidskou společnost. Jelikož antropologové uznávali, že kulturní a sociální systém mohou utvářet různorodé formy manželství, stoupenci názoru, že monogamní a nerozlučné manželství představuje civilizační pokrok ve srovnání s prvotní promiskuitou, se ocitli v mimořádně obtížné situaci, kdy museli vysvětlovat, čím je civilizovanější než jeho předchůdci. Přitom také museli zaujmout vlastní stanovisko v soudobých debatách o manželství jakožto smlouvě a jejich názory se často rozcházely. W. Robertson Smith ve studii o Př́buzenství a manželství ve staré Arábii (1885) tvrdil, že patrilineární monogamie podporuje „pokrok směrem k civilizovaným idejím partnerské věrnosti“ , protože ženu staví „zvláště pod ochranu jednoho muže“, což je názor, který předpokládá, že v civilizovaném manželství manžel zůstává silnější než manželka [Robertson Smith 1963: 166, 146]. ${ }^{34}$ Podle jiných autorů byla polygamie něčím primitivním, protože se muž zmocňoval svých žen násilím, zatímco monogamie byla civilizovaná, protože se jevilo jako pravděpodobnější, že se opírá o ženin souhlas. Ač je Engels

\footnotetext{
32 Tento citát a všechny další pocházejí z Bachofenovy knihy Mateřské právo, poprvé vydané $\mathrm{v}$ roce 1861 a publikované ve zkrácené podobě ve zde citovaném svazku; další odkazy jsou uvedeny v závorce přímo v textu. Bachofen psal německy a jeho dílo dosud nebylo celé přeloženo do angličtiny, ale angličtí antropologové, kterými se zde zabýváme, je znali. McLennan četl Bachofenovy práce, ale tvrdil, že na nich není závislý, nebot' je neměl přečtené celé v době, kdy publikoval podobné názory [viz McLennan 1866: 582].

${ }^{33}$ Gillian Beer se zabývá antiuniverzalistickým chápáním sociálních struktur a zákona u Simcox v [Beer 2001: 255, 262, 264].

34 Všechny další odkazy na tuto knihu se vztahují ke zde citovanému vydání a jsou uvedeny $\mathrm{v}$ závorce přímo $\mathrm{v}$ textu.
} 
znám svým výrokem, že monogamie, daleka toho, aby byla „smířením muže se ženou", je "porobením jednoho pohlaví druhým" [Engels 1967: 98], ${ }^{35}$ tato jeho poznámka opačného vyznění měla za cíl otřást obecně přijímanou moudrostí, že pouze v monogamním manželství „„žena zaujímá postavení rovné muži“ [Lecky 1902: 279]. Lecky ve svých Dějinách evropské morálky (1869) napsal: „(V)eškerou civilizační tendencí je zmenšovat rozdílnosti mezi různými členy rodiny“; přechodem k monogamii „se žena z pouhé otrokyně stává družkou a osobou rovnou manželovi." Pouze se zánikem praxe kupování manželek a zavedením monogamního manželství manželka "přestala být (manželovou - pozn. aut.) otrokyní a stala se do jisté míry smluvní stranou" [Lecky 1902: 297-8, 277]. Lecky tedy souhlasil se slavnou formulací Henryho Maina, podle které je chod dějin pohybem od statusu ke smlouvě, ,"svobodnému souhlasu jednotlivcü“ (163).

Tak jako vedli spory o tom, jestli monogamní manželství znamená, že manželé se stávají rovnými smluvními stranami, antropologové se navzájem lišili i v názorech na to, zda monogamní manželství je možné sloučit s právními definicemi smlouvy jakožto zrušitelné dohody mezi jednotlivci, kterým zůstává právo dohodu z vlastního rozhodnutí ukončit. Maine zaujal silné stanovisko ve prospěch individuálních práv žen, když prohlásil, že křest́anské zákony o manželství „hluboce ubližují civilizaci“, protože upevňují ",nezpůsobilost provdaných žen vlastnit majetek" $(152,53)$ a znesnadňují manželkám dosáhnout rozvodu. Jiní autoři zase věřili, že smluvní manželství rozkládá civilizaci, jelikož rozlučitelnost manželství ohrožuje rovnost vzniklou tehdy, když křestáanské právo učinilo manželské pouto stejně trvalým pro manžela i manželku, stanovilo meze sexuálním vášním obou pohlaví a připravilo manžela o možnost podle libosti manželku zapudit. V článku „Manželství a moderní civilizace“ (1901) nazval W. S. Lilly křestanské manželství „Magnou Chartou ženy v moderní civilizaci“, nebot' jím bylo manželství ustanoveno jako „celoživotní svazek dvou sobě rovných osobností“. Lilly varoval, „že degradace nerozlučného manželství na pouhou rozlučitelnou smlouvu ... znamená uvrhnout moderní civilizaci zpět do onoho válení v bahně, ze kterého jím byla vysvobozena" [Lilly 1901: 908, 909-10,919].

$\mathrm{V}$ některých případech se $\mathrm{v}$ otázce, zda rozlučitelné manželství ženy povznáší a rozvíjí civilizaci, jednotliví autoři rozcházeli sami se sebou. Robertson Smith popisoval předislámskou formu smluvního manželství, manželství mut’a, jako primitivnější než formy přisuzující manželovi a manželce nerovný status. V manželstvích mut'a byla žena nazývána "sadíqa“" ${ }^{\text {"36 }}$ neboli „př́ítelkyně“, což je vhodný termín pro smlouvu, v níž "manželka nepodléhá manželově autoritě, ale nachází se s ním na stejné úrovni“" (93). Smith manželství mut’a definoval jako

\footnotetext{
${ }^{35}$ Všechny další odkazy na tuto knihu se vztahují ke zde citovanému vydání a jsou uvedeny $\mathrm{v}$ závorce př́mo $\mathrm{v}$ textu.

${ }^{36}$ Výraz mut'a znamená „potěšení“ a používal se pro formu manželství sjednanou na dobu určitou existující pouze v šíitském právu, nikoli u sunnitů. Dle Robertsona Smithe je termín sadíqa odvozen ze slova sadaqa, označení pro svatební dar, který manžel při svatbě dával manželce (pozn. překl. - překladatel děkuje za konzultaci arabistovi Luboši Kropáčkovi).
} 
„čistě osobní smlouvu založenou na souhlasu mezi mužem a ženou bez jakéhokoli zasahování ze strany ženiných příbuzných“ (84). V manželství mut’a mají oba partneři právo na rozvod, žena zůstává v blízkosti svých příbuzných a všechny narozené děti patří jí $(83,85)$. Právo ženy rozvázat své manželství je spojeno $\mathrm{s}$,„jejím právem disponovat vlastní osobou“ (91). To však ztrácí v následující formě manželství, kterou Smith ve svém překladu nazývá "manželství nadvlády“ a v níž manžel vlastní „poddanou ženu“ (93). Na jednu stranu Smith manželství nadvlády kritizoval kvůli tomu, že se zakládá na únosu nebo koupi, a soudil, že islám zrušením manželství $m u t^{\prime} a$ „vtiskl ženskému pohlaví trvalou pečet' zotročení“ (121). Na stranu druhou však on sám manželství mut'a zařadil do primitivního, jednoduchého matrilineárního stadia předcházejícího patrilineárnímu př́buzenství (37).

Pod příbuzenství patří rodičovství stejně jako manželství a antropologové vedli spory i o tom, kam je třeba na civilizační škále umístit různé podoby mezigeneračních vztahů. Ti z nich, kteří za cíl manželství pokládali biologickou reprodukci, prohlašovali za ústřední prvek manželského svazku sexuální rozdílnost. Jiní byli ochotni zabývat se možností, že spíše než sexuální rozdílnost má vztah mezi rodiči a dětmi a také vztah mezi manželi definovat smlouva. Maine kupříkladu projevoval velký zájem o staré římské adopční právo, ,jež umožňovalo umělou tvorbu rodinných vztahů" (125), čímž se příbuzenství a občanství stávalo nezávislým na biologické reprodukci. Adopční právo vzniklo ze spojení mezi patria potestas a myšlenkou, že rodina tvoří základ státu. Aby bylo možné do státu přijímat nové lidi, bylo nutné o nich uvažovat jako o biologických příbuzných, ale ve společnosti, která rodinu definovala pouze prostřednictvím otcovské autority, se pocházet ze stejné krve stalo méně důležitým než podléhat stejné otcovské moci (144). Adoptivní děti se tak těšily stejnému statusu jako biologické potomstvo. S postupem doby patria potestas ztratila na významu, ale právní fikce adopce - neboli, jak uvádí Maine, "falešné rozšiřování pokrevnosti“ (127) - zůstala možností, jak udržet a zvětšit rodinu jinak než manželstvím a heterosexuální reprodukcí (125). Jelikož sociální představivost v oblasti společenských vazeb se i nadále opírala o adoptivní i biologickou rodinu, adopce se stala také modelem pro vytváření politických společenství, která se nezakládala na sdílené krvi.

Maine se domníval, že adopce je pro civilizaci nesmírně důležitá, a tvrdil, že ztotožňování rodiny s heterosexuální reprodukcí je přežitkem primitivní kultury: „(B)ez ... fikce adopce, jež umožňuje umělé vytváření rodinných pout, je obtížné pochopit, jak se společnost kdy mohla vymanit z plenek a učinit první krůčky směrem k civilizaci“ (26). Adopce ukazuje, že "o uspořádání stavu, o němž se obecně má za to, že byl přirozený, se přesto vědělo, že je do značné míry umělý. ... Nejstarší a nejčastěji používanou právní fikcí byla ta, která umožňovala umělé vytváření rodinných vztahů, a neznám žádnou jinou, jíž by lidstvo bylo hlouběji zavázáno" (125-26). Také Edith Simcox ve své oslavné studii Primitioní civilizace psala o tom, že adopce byla velmi rozšířená ve staré Babylónii, kde ženy měly řadu občanských práv, ideálem bylo rovnostářské manželství a „adopční 
akty (byly - pozn. aut.) vykonávány s formalitami velmi podobnými formalitám spojeným s manželskými smlouvami“ (377). Podle Maina a Simcox civilizační pokrok závisel na konceptualizaci vztahu mezi rodičem a dítětem, podobně jako mezi manželem a manželkou, jakožto právní formy, jež z příbuzenství činila zkonstruovanou dohodu mezi jednotlivci. Možná nepřekvapí, že adopce byla spojována také s láskou mezi osobami stejného pohlaví; ve 40. letech 19. století publikoval jeden vytříbený pornografický žurnál esej o „Sapfiných láskách“ uvádějící příklady římských patricijů, kteří adopcí formalizovali svou „osobní lásku“ k atraktivním chlapcům [The Loves n.d.: 82, 83].

\section{Svazky osob stejného pohlaví a dějiny civilizace}

Sledování toho, jak antropologické texty chápaly vztah mezi manželstvím a smlouvou, nás vrátilo $\mathrm{k}$ otázce svazků mezi osobami stejného pohlaví. Historická retrospektiva ukazuje, že smlouva vyvracela představu, podle níž je příbuzenství závislé na sexuální rozdílnosti, ale věnovaly se viktoriánské dějiny manželství vůbec někdy explicitně svazkům osob stejného pohlaví, a pokud ano, kam je zařazovaly na svých hodnotících škálách? Odpověd’ na tuto otázku mưžeme začít poukazem $\mathrm{k}$ tomu, že někteří antropologové zastávající názor, že podstata manželství není definována sexuální rozdílností, náleželi k sociálním sítím, jež zahrnovaly i ženy žijící v ženských manželstvích. Edith Simcox nikdy s žádnou ženou nežila, ale znala se se ženami z ženských párů a trojúhelníků. Charles Darwin a Henry Sumner Maine znali Frances Power Cobbe natolik dobře, aby věděli, že žije společně s Mary Lloyd. Darwinův otec se znal s dámami z Llangollen, ${ }^{37}$ jinou slavnou ženskou dvojicí, a sám Darwin bydlel blízko Cobbe a Lloyd, když pracoval na Pưvodu člověka. V té době Lloyd pưjčila svému sousedovi Darwinovi poníka a on ji stejně jako další členové jejich okruhu považoval za partnerku Cobbe. Když psal Cobbe, mluvil o „Tobě a slečně Lloyd“. ${ }^{8}$ Ač si dnes badatelé nejsou jisti tím, zda Maineův liberální individualismus vedl ke konzervativnímu nebo progresivnímu pohledu na manželství, Cobbe Maina pokládala za spojence feministek, jehož „zájem o požadavky žen a ... silné výroky na toto téma způsobily, že jsem k němu pohlížela s velkou vděčností" [Cobbe 1894: vol. 2, 436].39

Několik málo účastníků viktoriánských diskusí o manželství explicitně tematizovalo roli, kterou svazky mezi osobami stejného pohlaví sehrávaly v pro-

\footnotetext{
37 Již dříve zmíněné Eleanor Butler (1739-1829) a Sarah Ponsonby (1755-1832), dvě ženy z aristokratických vrstev, které se odmítly provdat za muže a žily společně na svém sídle blízko města Llangollen ve Walesu (pozn. překl.).

${ }^{38}$ O Cobbe, Lloyd a Darwinovi viz Cobbe [1894: 445, 447]; o půjčení poníka Darwinovi viz Cobbe [1904: 486]. Ke známosti mezi Darwinovým otcem a dámami z Llangollen viz Mavor [1984: 36, 69].

39 Maine také feministkám dovolil, aby v rámci kampaně za reformu zákonů upravujících vlastnické poměry provdaných žen přetiskly jeho přednášku z roku 1873 nazvanou „Raná historie vlastnictví vdaných žen" [viz Feaver 1969: 302, n.22].
} 
gresivistických vyprávěních o příbuzenství. Někteří z nich se na tyto svazky dívali přesně tak, jak bychom mohli očekávat na základě toho, jak antropologickou teorii čte Gayle Rubin: jako na praxi antitetickou k příbuzenství, přípustnou pouze ve stavech předsociálního a předkulturního divošství a primitivní promiskuity. Lecky kupř́kladu ztotožňoval polygamii s pederastií. Jeho přirozené dějiny morálky podrobně analyzovaly "ctnosti ... odpovídající každému následnému stadiu civilizace“ (ix) a upozorňovaly, že „(j)sou-li vášně mužů zcela nespoutané, stanou se přípustnými společenstva manželek a všechny další excentrické formy smyslnosti“ (103). Lecky propojoval hojný výskyt kurtizán v antickém Řecku s holdováním mužů „,oné ještě nižší propasti nepřirozené lásky, jež představovala nejhlubší a nejpodivnější poskvrnu řecké civilizace," označované v jedné poznámce pod čarou jako „pederastie“ (294) a ztotožněné s přiběhem o Harmodiovi a Aristogeitónovi, "spojenými nečistou láskou“ (295). Engels v Počátcích rodiny, soukromého vlastnictví a státu rozvinul opačnou argumentaci, která vyzdvihovala kolektivismus primitivních společenských forem nad individualismus forem moderních. Zatímco Lecky považoval homosexualitu za př́iznačnou pro společnosti před příchodem křest́anství, Engels homosexualitu líčil jako výsledek rozmachu soukromého vlastnictví a monogamní rodiny. Poznamenávaje, že historicky monogamie vždy existovala ,jen pro ženu, ale ne pro muže“ (96), kritizoval starořecké manželství za to, že poskvrňovalo manželky a podporovalo sodomii mezi muži: „to, že zbavili ženu důstojnosti, se mužům vymstilo a připravovalo je samotné o důstojnost, až propadli zvrácené lásce $\mathrm{k}$ chlapcům a potupili své bohy i sebe mýtem o Ganymédovi“" (97). ${ }^{40}$

I když Engels sdílel s Leckym odmítavý názor na aténskou pederastii a v dopise Karlu Marxovi se kousavě vyjadřoval o "uranovcích“, ${ }_{1}^{41}$ nevědomky tvrdil, že manželství mezi osobami stejného pohlaví je součástí toho stadia vývoje příbuzenství, které považoval za nejzajímavější: doby, „,dokud nebylo vynalezeno krvesmilstvo", kdy rodinu tvořil "princip promiskuity - nepř́tomnosti jakýchkoli omezení uvalených zvykem na pohlavní styk" (71-2; český překlad upraven). Engels popisoval ranou příbuzenskou strukturu zvanou rodina pokrevních příbuzných, v níž „(b)ratři a sestry, bratranci a sestřenice prvního, druhého nebo vzdálenějšího stupně jsou navzájem všichni bratry a sestrami, a právě proto jsou si všichni navzájem manželi a manželkami“ (72; český překlad upraven). „Všichni navzájem manželi a manželkami“" - Engels považuje za samozřejmé, že pouze muži mohou být manželi žen a pouze ženy manželkami mužủ. Ale právě proto dospívá k větě, která doslova říká, že v primitivní rodině je každý zároveň manželem $i$ manžel-

${ }^{40}$ Engels také tvrdí, že svoboda a úcta, kterým se těšily ženy ve starých germánských společnostech, byly spojeny s párovou rodinnou formou, která předcházela „,křiklavým mravním rozporům" monogamie [Engels 1967: 102]. Párovou rodinu staví do protikladu k morálnímu úpadku, který Germány postihl při stěhování na východ, kde „přejali ... kromě jezdeckého umění také těžké neřesti proti přirozenosti“ [1.c.]. Engels ztotožnil Orient se sodomií a obojí považoval za produkt rozvíjejícího se kapitalismu.

${ }^{41}$ Z německého "Urning“, termínu zavedeného v polovině 19. století publicistou Karlem Heinrichem Ulrichsem jako označení pro homosexuální muže (pozn. překl.). 
kou všech ostatních bez ohledu na pohlaví. Když píše, že „(b)ratři a sestry ... jsou navzájem všichni bratry a sestrami“, užívá př́ibuzenských výrazů, které nejsou omezovány pohlavím jejich předmětu: ženy jsou sestrami žen i mužů. Tato genderová inkluzivita se gramaticky prodlužuje až do poslední věty souvětí, která se obrací k sexuálním vztahům; syntaxe transformuje sémantiku, takže „manžele a manželky“ lze definovat stejně jako sourozenectví, které je určuje. Ženy jsou manželkami svých sester a bratrů, muži jsou manželi svých bratrů a sester.

Engels se dopouští stejného gramatického faux pas, když hovoří o punaluanské rodině, v níž je několik sester společnými manželkami společných manželů, kteří na rozdíl od pokrevních manželství nejsou bratry mezi sebou a nejsou ani bratry sester, se kterými se žení. Výraz „punalua“ se netýká vztahů mezi různými pohlavími, ale vztahů stejnopohlavních: „muži ... se však už mezi sebou nenazývali bratry, jimiž už ani být nemuseli, nýbrž punalua, což značí důvěrný druh, cosi jako partner. Právě tak měla řada vlastních nebo vzdáleněǰších bratřrí ve společném manželství určitý počet žen, nikoli však své sestry, a tyto ženy si navzájem rovněž říkaly punalua“ (74). V této „klasické formě rodinného útvaru, ... jehož podstatným charakteristickým rysem bylo vzájemné společenství mužů a žen uvnitř určitého rodinného kruhu," jsou manželky intimními partnerkami jiných manželek, manželé důvěrnými společníky jiných manželů (74-5) a manželství vytváří vztahy mezi ženami a mezi muži stejně tak jako mezi muži a ženami.

Engels bezděky dospěl k tvrzení, že vztahy mezi osobami stejného pohlaví byly součástí primitivního skupinového manželství, a tak stejnopohlavní svazky ztotožnil s formou incestu, již oceňoval pro její skupinovou harmoničnost. Naproti tomu Johann Bachofen stejnopohlavní svazky výslovně označoval za znak civilizace a modernity. V Mateřském právu (1861) Bachofen napsal o sexuálních vztazích v primordiální přírodě, že jsou zaměřené na reprodukci, oplodnění, naplnění potřeb pouze materiálního světa a výlučně heterosexuální. Civilizace se může rozvinout, až když ženy a muži vystoupí z primitivního stavu, jejž Bachofen nazývá ",hetérismem“, v němž sexualita je plná násilí a spojuje se pouze s biologickou reprodukcí. V dlouhé pasáži o Sapfó, ve své době neobvyklé pro otevřený způsob vyjadřování o jejích sexuálních vztazích se ženami, Bachofen Sapfó označuje za "cudnou“, a cudnost definuje ne jako nepř́itomnost sexuality, ale jako její idealizující regulaci:

Ženská láska k vlastnímu pohlaví (v lesbické poezii - pozn. aut.) byla obdobou orfické (mužské homosexuality - pozn. aut.). ... Sapfino snažení o povznesení vlastního pohlaví bylo zdrojem všech jejích zármutků i radostí a byl to Érós sám, kdo ji podněcoval $\mathrm{k}$ jejím pokusům. Její vášnivá slova neprýštila z mateřské starostlivosti, ale z milostné vášně, avšak tento entusiasmus, který se stejnou silou uchvacoval smyslné i transcendentní, tělesné i duševní, měl svůj poslední a nejbohatší zdroj v náboženství. Láska a identita pohlaví, jež se zdály navzájem vylučovat, se nyní spojily [Bachofen 1967: 204-5]. 
Podle Bachofena je lesbismus, stejně jako monogamní manželství, formou kultury, nebot vyžaduje jistý stupeň sebeomezení; obě proměňují materialistický chtíč v duchovní lásku, aniž by se zřekly smyslnosti. Ve svém výkladu sapfické lásky jako pokročilého stadia civilizace Bachofen implicitně polemizoval s každým absolutním ztotožněním civilizace s heterosexuální monogamií a reprodukcí.

Jestliže Evropané 19. století jednotně nepředpokládali, že svazek muže a ženy je jedinou civilizovanou formou manželství, bylo tomu tak zčásti díky groteskní heterogenitě veřejného mínění $\mathrm{v}$ otázce, jakou podobu by manželství mělo mít. Pro 50. a 60. léta byly příznačné spory, nikoli shoda, o tom, co tvořilo manželství a rodinu, a vztahy mezi osobami stejného pohlaví byly pro tyto debaty inspirací. Účastníci př́íslušných diskusí znali $\mathrm{v}$ různé míře ženy žijící $\mathrm{v}$ ženských manželstvích a někteří historici manželství explicitně nebo implicitně tvrdili, že stejnopohlavní vztahy jsou slučitelné s takovými hodnotami, jako je ctihodnost, civilizovanost a pokrok. To neospravedlňuje empirické a etické nedostatky systémů, které vytrvale diskriminovaly mnohá náboženství, národy a epochy. Ale upozorňuje nás to na klíčové rozdíly mezi konceptem homosexuality typickým pro dvacáté století a zvyklostí ženských manželství vlastní století devatenáctému. Homosexuál a lesba byli definováni utajeností, stigmatem a asociální odchylkou od sezdaných párů, zatímco ženy žijící v ženských manželstvích měly své místo v sociálním systému jako přijatelná variace k legálním dvojicím.

Po řadu desetiletí badatelky a badatelé spoutaní předsudky vlastními až dvacátému století fakta o ženském manželství století devatenáctého zatemňovali, a následkem toho se teprve nedávno stalo možným popsat roli, již ženská manželství sehrála v politickém, společenském a intelektuálním životě. Do 90. let 20. století životopisy Charlotte Cushman, Frances Power Cobbe, Anne Lister nebo Emily Faithfull vůbec nezmiňovaly jejich vztahy se ženami, leda snad s cílem př́liš silně zdůraznit, že to byla naprosto asexuální přátelství. Novější výzkum odhalil sexuální povahu těchto vztahů, ale přitom je získal pro lesbickou historii tím, že zdůraznil jejich okrajovost a protikladnost k manželství. Rosa Bonheur a Charlotte Cushman však byly mezinárodní hvězdy milované veřejností a napojené na umělecké a intelektuální osobnosti prvního rangu, které otevřeně žily se ženami, jež pokládaly za své partnerky. Frances Power Cobbe nikdy netrpěla obavami, že by její dobře známý vztah s Mary Lloyd mohl ohrozit její postavení šampionky ženských práv v manželství i mimo ně. Autoři jako Henry Sumner Maine a John Stuart Mill hájili definice manželství, které zdưrazňovaly výhody rovnosti a podobnosti mezi partnery. Johann Bachofen výslovně spojil lesbismus s moderním osvícením.

Jednou z velkých lží dnešních civilizačních vyprávění je ta, že v minulosti byly hodnoty pevně dány a že až do velmi nedávné doby vládla naprostá shoda v tom, že manželské vztahy mohou existovat pouze mezi mužem a ženou. 
Už před 150 lety však byly viktoriánské hodnoty v pohybu. Zákonodárci, novináŕi a antropologové vedli diskuse o legitimitě rozvodu a významu manželství. Zatímco mnozí varovali, že konec civilizace se blíží, mnozí jiní zase věřili, že rozlučitelné svazky mezi právně si rovnými partnery představují budoucnost manželství - v neposlední řadě díky př́íladu poskytnutému ženskými manželstvími jejich doby.

Z angličtiny přeložil Marek Skovajsa.

SHARON MARCUS je profesorkou anglické a komparationí literatury na katedře literatury Columbia University v New Yorku. Zaměruje se na britskou a francouzskou literaturu 19. století a zejména viktoriánské epochy. Ve svém př́stupu spojuje feministickou literární teorii a gay, lesbická, bisexuální a transgenderová studia. Je autorkou monografí Apartment Stories: City and Home in Nineteenth-Century Paris and London (Berkeley: University of California Press, 1999) a Between Women: Friendship, Desire, and Marriage in Victorian England (Princeton: Princeton University Press, 2007). V současnosti pracuje na nové monografii o Oscaru Wildovi, Sarah Bernhardt a dalších hereckých hoězdách 19. století.

\section{Literatura}

Anderson, N. F. 1987. Women against Women in Victorian England: A Life of Eliza Lynn Linton. Bloomington: Indiana University Press.

Bachofen, J. J. 1967. Myth, Religion, and Mother Right: Selected Writings of J. J. Bachofen. Princeton: Princeton University Press.

Barkan, E. 1995. „Victorian Promiscuity: Greek Ethics and Primitive Exemplars.“ Pp. 56-92 in E. Barkan, R. Bush (eds.). Prehistories of the Future: The Primitivist Project and the Culture of Modernism. Stanford: Stanford University Press.

Battersea, C. 1922. Reminiscences. London: Macmillan.

Beer, G. 2001. „Knowing a Life: Edith Simcox-Sat est vixisse?“ Pp. 252-266 in S. Anger (ed.). Knowing the Past: Victorian Literature and Culture. Ithaca: Cornell University Press.

Bloomfield, G. 1883. Reminiscences of Court and Diplomatic Life. Vol. 2. London: Kegan, Paul, Trench \& Co.

Borneman, J. 1996. „Until Death Do Us Part: Marriage/ Death in Anthropological Discourse." American Ethnologist 23 (2): 215-238.

Boswell, J. E. 1994. Same-Sex Unions in Premodern Europe. New York: Villard Books.

Browning, R. 1951. Dearest Isa: Robert Browning's Letters to Isabella Blagden. Austin: University of Texas Press.

Bush, G. W. 2004. „Transcript of Bush statement.“ CNN.com [online] February 24 [cit. 10. 8. 2009]. Dostupné z: <http://www.cnn.com/2004/ALLPOLITICS/02/24/elec04. prez.bush.transcript/index.html>.

Butler, J. 1990. Gender Trouble: Feminism and the Subversion of Identity. New York: Routledge. 
Butler, J. 2000. Antigone's Claim: Kinship Between Life and Death. New York: Columbia University Press.

Butler, J. 2003. Trampoty s rodom. Feminizmus a podrývanie identity. Bratislava: Aspekt.

Butler, J. 2004. Undoing Gender. New York: Routledge.

Carr, C. (ed.). 1913. Harriet Hosmer: Letters and Memories. London: John Lane, The Bodley Head.

Chauncey, G. 2004. Why Marriage? The History Shaping Today's Debate over Gay Equality. New York: Basic Books.

Cobbe, F. P. 1862. „Celibacy v. Marriage.“ Fraser's Magazine 65 (February): 228.

Cobbe, F. P. 1878. „Wife-Torture in England.“ Contemporary Review 32 (April): 55-87.

Cobbe, F. P. 1881. The Duties of Women: A Course of Lectures. London: Norgate.

Cobbe, F. P. 1894. Life of Frances Power Cobbe. By Herself. Vol. 2. Boston: Houghton, Mifflin.

Cobbe, F. P. 1904. Life of Frances Power Cobbe. London: Swan Sonnenschein.

Cobbe, F. P. (1862) 1996. „What Shall We Do with Our Old Maids?“ Pp. 236-261 in A. Broomfield, S. Mitchell (eds.). Prose by Victorian Women: An Anthology. New York: Garland.

Coontz, S. 2005. „The Heterosexual Revolution.“ New York Times 155 (53282): A17.

Cornwallis, C. 1857. „The Capabilities and Disabilities of Women." Westminster Review 67 (1): $42-72$.

Craik, D. M. (1850) 1999. Olive. New York: Oxford University Press.

„Cross-dressing Women." 2001. Pp. 11-34 in A. Oram, A. Turnbull (eds.). The Lesbian History Sourcebook: Love and Sex Between Women in Britain from 1780 to 1970. London: Routledge.

Darwin, C. (1859) 1985. The Origin of Species by Means of Natural Selection or the Preservation of Favoured Races in the Struggle for Life. London: Penguin.

„Divorce a Vinculo; or, the Terrors of Sir Cresswell Cresswell.“ 1860. Once a Week 2 (February 25): 184-87.

Engels, B. 1967. „Původ rodiny, soukromého vlastnictví a státu.“ Pp. 55-203 in K. Marx, B. Engels. Spisy, svazek 21. Praha: Svoboda.

Engels, F. (1884) 1972. The Origin of the Family, Private Property and the State. New York: International Publishers.

Eribon, D. 2005. Echapper à la psychanalyse. Paris: Editions Léo Scheer.

Faderman, L. 1981. Surpassing the Love of Men: Romantic Friendship and Love Between Women from the Renaissance to the Present. New York: William Morrow.

Fahnestock, J. 1981. „Bigamy: The Rise and Fall of a Convention.“ Nineteenth-Century Fiction 36 (1): 47-71.

Feaver, G. 1969. From Status to Contract: A Biography of Sir Henry Maine 1822-1888. London: Longmans, Green \& Co.

Fee, E. 1974. „The Sexual Politics of Victorian Social Anthropology.“ Pp. 86-102 in M. S. Hartman, L. Banner (eds.). Clio's Consciousness Raised: New Perspectives on the History of Women. New York: Harper Colophon.

Firth, R. (1861) 1963. „Preface.“ In H. S. Maine. Ancient Law: Its Connection with the Early History of Society and Its Relation to Modern Ideas. Boston: Beacon Press.

Fison, L., A. W. Howitt. 1880. Kamilami and Kurnai: Group-Marriage and Relationship, and Marriage by Elopement. Melbourne: George Robertson.

Foucault, M. 1999. Vuile k vědění. Dějiny sexuality I. Praha: Hermann \& synové.

Frost, G. 1997. „Bigamy and Cohabitation in Victorian England.“ Journal of Family History 22 (3): 286-306.

Gillis, J. R. 1985. For Better, For Worse: British Marriages, 1600 to the present. New York: Oxford University Press. 
„Gleanings from Dark Annals: Modern Amazons." 1863. Chambers's Journal of Popular Literature, Science and Arts 19 (491): 348-351.

Greenwell, D. 1862. „Our Single Women.“ The North British Review 36 (February): 62-87.

Greg, W. R. 1873. „Why Are Women Redundant?“ Pp. 274-308 in W. R. Greg. Literary and Social Judgements. Boston: James R. Osgood.

Hays, M. 1846. Helen Stanley: A Tale. London: E. Churton.

Hays, M. 1866. Adrienne Hope: The Story of a Life. London: T. Cautley Newby.

Hellerstein, E. O., L. Parker Hume, K. M. Offen (eds.). 1981. Victorian Women: A Documentary Account of Women's Lives in Nineteenth-Century England, France, and the United States. Stanford: Stanford University Press.

Hertzberg, H. 2003. „Dog Bites Man.“ New Yorker [online] May 5 [cit. 1. 8. 2009]. Dostupné z: <http://www.newyorker.com/archive/2003/05/05/030505ta_talk_hertzberg>.

Holcombe, L. 1983. Wives and Property: Reform of the Married Women's Property Law in Nineteenth-Century England. Toronto: University of Toronto Press.

Holmes, O. W. (1881) 1963. The Common Law. Cambridge, MA: The Belknap Press of Harvard University Press.

Horstman, A. 1985. Victorian Divorce. London: Croom Helm.

Incorvati, R. 2001. „Introduction: Women's Friendships and Lesbian Sexuality." Nineteenth-Century Contexts 23 (2): 175-186.

James, H. (1903) 1969. William Wetmore Story and His Friends: From Friends, Diaries, and Recollections. Vol. 1. New York: Da Capo Press.

Kaye, R. A. 2002. The Flirt's Tragedy: Desire without End in Victorian and Edwardian Fiction. Charlottesville: University Press of Virginia.

Klumpke, A. (1908) 1997. Rosa Bonheur: The Artist's (Auto)biography. Ann Arbor: University of Michigan Press.

Kuper, A. 1988. The Invention of Primitive Society: Transformations of an Illusion. London: Routledge.

Leckie, B. 1999. Culture and Adultery: The Novel, the Newspaper, and the Law, 1857-1914. Philadelphia: University of Pennsylvania Press.

Lecky, W. (1869) 1902. History of European Morals from Augustus to Charlemagne. Vol. 2. London: Longmans, Green.

Letters of Mary Mathison. 1875. London: for private circulation only.

Lévi-Strauss, C. 1969. The Elementary Structures of Kinship. Boston: Beacon Press.

Lévi-Strauss, C. 1981. Les Structures élémentaires de la parenté. Paris: Mouton.

Liddington, J. 1998. Female Fortune: Land, Gender and Authority. The Anne Lister Diaries and Other Writings. London and New York: Rivers Oram Press.

Lilly, W. S. 1901. „Marriage and Modern Civilization.“ Nineteenth Century and after 50 (298): 905-919.

Lubbock, J. (1870) 1978. The Origin of Civilisation and the Primitive Condition of Man. Chicago: University of Chicago Press.

Lucey, M. 2003. The Misfit of the Family: Balzac and the Social Forms of Sexuality. Durham, NC: Duke University Press.

Maine, H. S. (1861) 1963. Ancient Law: Its Connection with the Early History of Society and Its Relation to Modern Ideas. Boston: Beacon Press.

Markus, J. 2000. Across an Untried Sea: Discovering Lives Hidden in the Shadow of Convention and Time. New York: Alfred A. Knopf.

Mavor, E. (ed.). 1984. Life with the Ladies of Llangollen. New York: Viking.

McLennan, J. F. 1865. Primitive Marriage: An Inquiry into the Origin of the Form of Capture in Marriage Ceremonies. Edinburgh: Adam and Charles Black. 
McLennan, J. E. 1866. „Kinship in Ancient Greece, Part I.“ Fortnightly Review 4: 569-588.

Merrill, L. 1999. When Romeo Was a Woman: Charlotte Cushman and Her Circle of Female Spectators. Ann Arbor: University of Michigan Press.

Mill, J. S. 1970a. „Early Essays on Marriage and Divorce.“ Pp. 65-88 in J. S. Mill, H. Taylor Mill. Essays on Sex Equality. Chicago: University of Chicago Press.

Mill, J. S. 1970b. „The Subjection of Women." Pp. 123-242 in J. S. Mill, H. Taylor Mill. Essays on Sex Equality. Chicago: University of Chicago Press.

Mitchell, S. 2004. Frances Power Cobbe: Victorian Feminist, Journalist, Reformer. Charlottesville: University of Virginia Press.

„Old Maids.“ 1860. Dublin University Magazine 56 (December).

Parkes, B. R. 1866. Vignettes: Twelve Biographical Sketches. London: Alexander Strahan.

Psomiades, K. 1999. "Heterosexual Exchange and Other Victorian Fictions: The Eustace Diamonds and Victorian Anthropology." Novel 33 (1): 93-118.

Ritchie, H. (ed.). 1924. Letters of Anne Thackeray Ritchie. London: John Murray.

Robertson Smith, W. (1885) 1963. Kinship and Marriage in Early Arabia. Boston: Beacon Press.

Roden, F. S. 2002. Same-Sex Desire in Victorian Religious Culture. Houndmills: Palgrave Macmillan.

Rubin, G. 1975. „The Traffic in Women: Notes toward a Political Economy of Sex." Pp. 157-210 in R. Reiter (ed.). Toward an Anthropology of Women. New York: Monthly Review Press.

Savage, G. 1992. „,Intended Only for the Husband': Gender, Class, and the Provision for Divorce in England, 1858-1868." Pp. 11-42 in K. O. Garrigan (ed.). Victorian Scandals: Representations of Gender and Class. Athens: Ohio University Press.

Shanley, M. L. 1982. ",'One Must Ride Behind': Married Women's Rights and the Divorce Act of 1857." Victorian Studies 25 (3): 355-76.

Shanley, M. L. 1989. „A Husband's Right to His Wife's Body: Wife Abuse, the Restitution of Conjugal Rights, and Marital Rape." Pp. 156-188 in M. L. Shanley. Feminism, Marriage, and the Law in Victorian England Princeton: Princeton University Press.

Sherwood, D. 1991. Harriet Hosmer: American Sculptor 1830-1908. Columbia: University of Missouri Press.

Sigel, L. Z. 2002. Governing Pleasures: Pornography and Social Change in England, 1815-1914. New Brunswick, N.J.: Rutgers University Press

Simcox, E. J. 1894. Primitive Civilizations or Outlines of the History of Ownership in Archaic Communities. London: Swan Sonnenschein.

Sinks of London Laid Open. 1848. London: J. Duncombe.

van Slyke, G. 1993. „Who Wears the Pants Here? The Policing of Women's Dress in Nineteenth-Century England, Germany and France." Nineteenth-Century Contexts 17 (1): 17-33.

Smith-Rosenberg, C. 1996. „The Female World of Love and Ritual: Relations between Women in Nineteenth-Century America." Pp. 366-97 in Joan Wallach Scott (ed.). Feminism and History. Oxford: Oxford University Press.

Somerville, M. 1873. Personal Recollections, from Early Life to Old Age, of Mary Somerville. London: John Murray.

Stebbins, E. 1879. Charlotte Cushman: Her Letters and Memories of Her Life. Boston: Houghton, Osgood.

Stetson, D. 1982. A Woman's Issue: The Politics of Family Law Reform in England. Westport: Greenwood Press.

Stocking, G. W. Jr. 1987. Victorian Anthropology. New York: The Free Press,.

Stone, L. 1979. Family, Sex and Marriage in England 1500-1800. New York: HarperCollins. 
Taylor, B. 1983. Eve and the New Jerusalem: Socialism and Feminism in the Nineteenth Century New York: Pantheon Books.

Thackeray Ritchie, A. (1861) 1876. „Toilers and Spinsters.“ Pp. 1-35 in A. Thackeray Ritchie. Toilers and Spinsters and Other Essays. London: Smith, Elder, \& Co.

„The Lady and Her Marriage Settlement." 1864. Englishwoman's Domestic Magazine 47.

„The Loves of Sappho." n.d. The Exquisite (7).

Townsend, C. 1996. „I Am the Woman for Spirit‘: A Working Woman's Gender Transgression in Victorian London.“ Pp. 214-33 in A. H. Miller, J. E. Adams (eds.). Sexualities in Victorian Britain. Bloomington: Indiana University Press.

Vanita, R. 1996. Sappho and the Virgin Mary: Same-Sex Love and the English Literary Imagination. New York: Columbia University Press.

Vicinus, M. 2004. Intimate Friends: Women Who Loved Women, 1778-1928. Chicago: University of Chicago Press.

Wheelright, J. 1989. Amazons and Military Maids: Women Who Dressed as Men in Pursuit of Life, Liberty and Happiness. London: Pandora.

Whiting, L. 1911. The Brownings: Their Life and Art. Boston: Little, Brown \& Co.

Whiting, L. (ed.). 1940. Anna Elizabeth Klumpke. Memoirs of an Artist. Privately printed.

Woodhouse, M. K. 1959. „The Marriage and Divorce Bill of 1857." The American Journal of Legal History 3: 260-75. 